\title{
Ethics in Finance, Public Policies, and Institutions: The Latest Financial and Social Crises
}

\author{
Dr. Ioannis N. Kallianiotis \\ Economics/Finance Department, the Arthur J. Kania School of Management, University of Scranton, USA \\ *Corresponding Author: Dr. Ioannis N. Kallianiotis, Economics/Finance Department, the Arthur J. \\ Kania School of Management, University of Scranton, USA
}

\begin{abstract}
In this work are discussed some ethical issues regarding the financial market, the institutions, and the latest public policies. Morality and ethics are very important for a society and a nation and reveal the wellbeing of its structure, its business, its institutions, its policies, its government, its education, and its value system. All these foreshadow the future of the nation. In a country where ethics have been abandoned, we can easily predict its future. It has no future. The government has to impose regulations, laws and order, to keep the entire society at an advanced ethical level, after all this knowledge of thousands of years of history, civilization, experience, and revelation. Public policy (monetary and fiscal), institutions, organizations, and agencies must be headed based on ethical, fair, and moral foundations. The latest two financial, economic, and social crises, especially, the last one, the unethical coronavirus pandemic, the lockdowns, the election irregularities, could have been avoided or curtailed if the responsible generators of these crises were ethical and respectful towards the other people, other nations, and to our democratic system.
\end{abstract}

Keywords: Ethics, Financial Markets, Financial Institutions, Monetary Policy, Fiscal Policy, Financial Crises

\section{INTRODUCTION}

Financial markets and institutions have given to us, especially after the year 2000, countless scandals and news stories about financial professionals, central bankers, rating firms, governmental agencies, politicians, and others, who have defrauded investors, employers, peers, citizens, and the entire economy and have caused financial crises, recessions, and even economic and social destructions and chaos. There is no doubt that greed $(\dot{\alpha} \pi \lambda \eta \sigma \tau i \alpha),{ }^{1}$ fear, pride, selfishness, inefficiencies, waste, abuse of power, fraud, due to lack of regulations, are all powerful emotions and actions for our contemporary secular world. But sometimes unethical behavior boils down to a lack of morality and ethical education on basic principles of financial standards and behavior towards the fellow man and for social responsibility.

According to Engyclopedia, "Ethics ${ }^{2}$ in general is concerned with human behavior that is acceptable or "right" and that is not acceptable or "wrong" based on conventional morality. General ethical norms

\footnotetext{
${ }^{1}$ Greediness $(\dot{\alpha} \pi \lambda \eta \sigma \tau i ́ \alpha)$ is the basic cause of immorality, corruption, depravity, and all the sins of humans. See, Euthymios (1996, p. 40).

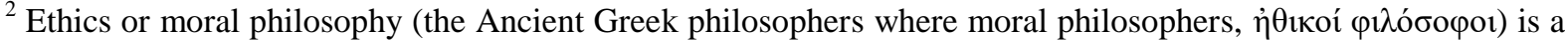
branch of philosophy that "involves systematizing, defending, and recommending concepts of right and wrong behavior". Also, it was enriched with the reviled TRUTH and reached the value system that the advanced cultures have the last 15 centuries, since the Justinian Code of Law. The field of ethics, along with aesthetics, concerns matters of value and virtues, and thus comprises the branch of philosophy called axiology ( $\dot{\alpha} \xi$ io $\left.{ }_{0} \gamma i \alpha\right)$, the philosophical study of value. Between the 5th and 6th centuries B.C., it was important in Greece to be knowledgeable, if you were to be successful. Philosophers began to recognize that differences existed between

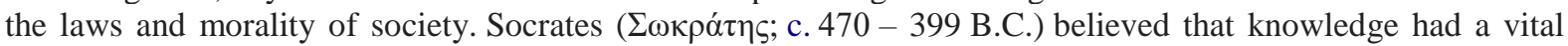

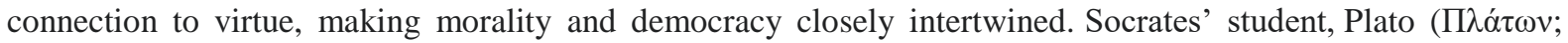
$428 / 427$ or $424 / 423-348 / 347$ B.C.) furthered the belief by establishing virtues, which should be followed by all. With the fall of the government, values became individual, causing skeptic schools of thought to flourish, ultimately shaping a pagan philosophy that is thought to have influenced and shaped Christianity. Thus, Ethics seeks to resolve questions of human morality by defining concepts such as good and evil, right and wrong,
} 
encompass truthfulness, honesty, integrity, respect for others, fairness, and justice. They relate to all aspects of life, including business and finance. Financial ethics is, therefore, a subset of general ethics." ${ }^{\prime 3}$ The major reasons for ethical lapses in the financial sector are the greed, the selfishness, and the fear of the participants because they have put all their interest in life on their money, on wealth maximization, and on material goods ( financially and very poor ethically. This is the current disorientation of man, the alienation of the human nature ( $\varphi \theta 0 \rho \alpha ́, \sigma \omega \mu \alpha \tau \iota \kappa o ́ \varsigma ~ \kappa \alpha i ́ ~ \pi v \varepsilon v \mu \alpha \tau ı \kappa o ́ \varsigma ~ \theta \dot{\alpha} v \alpha \tau o \zeta)$. The remedy, here, is true knowledge and regulation, which makes business legal, ethical, fair, and moral for all concerned parties. If the regulation favors any particular party to an extent, it is not fair, and therefore cannot be ethical.

Corporate governance tries to promote equity and ethics among top managers, workers, and customers, but it is very difficult without specific regulations and the existence of the self-interest of every one of these three groups. Corporate governance incorporates accountability among the top management, which is transferred to the middle and lower-level management and from them to the workers and all of them try to satisfy their customers and clients. One serious problem with the top management and executives is their compensation (salaries and benefits). ${ }^{5}$ Thus, self-regulation cannot be ethical because the self-interest is always above social interest. Public policies and institutions have to follow the laws and orders (constitution, legal elections, ${ }^{6}$ etc.) and to satisfy the wellbeing of the citizens of the country. Then, crises can be prevented or can be averted with minimum social cost.

\section{ETHICS IN FINANCIAL MARKETS}

Ethical issues in financial markets affect the clients (consumers of these services) and the entire economy because the confidence of people on our financial markets is a necessary factor for our investment and consumption decisions. The most watchable news is the growth of financial indexes during the day. The entire word is watching the value of the DJIA and what is going on with the Wall Street, which depends on information (surprises) during the evening news. An investor needs to trust the financial markets; otherwise, he does not use them for his investment. Financial scandals are common because this market is growing based on risk, fear, greed, and exploitation (irrational expectations).

The fundamental ethical requirement is that financial markets must provide what they have promised and be fair with their customers (suppliers and demanders of funds). The regulation in finance must be based on ethical issues, like fairness, truth, duties of fiduciaries, ${ }^{7}$ etc. Finance ethics is concerned not only with individual conduct, but also with the operation of financial markets and institutions. Financial managers, who try to satisfy firms' objective, maximization of shareholders wealth, raise also ethical issues. The monetary policy (excess liquidity) can create, beyond inflation, ethical problems (money and wealth illusions, risk to securities' investors and to society at large) ${ }^{8}$ with the artificial bubbles and their burst by speculators.

virtue and vice, justice and crime, truth and lie. See, Corpus Juris Civilis, https://en.wikipedia.org/wiki/ Corpus_Juris_Civilis

${ }^{3}$ See, https://www.encyclopedia.com/finance/finance-and-accounting-magazines/ethics-finance

${ }_{5}^{4}$ See, Euthymios (1996, p. 43).

${ }^{5}$ See, Kallianiotis (2015, pp. 57-60).

${ }^{6}$ See, Kallianiotis (2020b).

${ }^{7}$ A fiduciary is a person or organization that acts on behalf of another person to manage his assets. Essentially, a fiduciary owes to that other entity the duties of good faith and trust. The highest legal duty of one party to another, being a fiduciary requires being bound ethically to act in the other's best interests. A fiduciary might be responsible for general well-being, but often the task involves finances (managing the assets of another person, or of a group of people, etc.). Money managers, financial advisors, bankers, accountants, executors, board members, and corporate officers all have fiduciary responsibility.

8 The money supply from $\$ 7,464.4$ billion (1/7/2008) reached $\$ 15,567.3$ billion (3/9/2020) and became $\$ 19,108.3$ billion (11/16/2020). The DJIA from 6,547.05 on March 9, 2009 reached 30,046.24 on November 24, 




Figure1. Dow Jones Industrial Average (DJIA)

Source: Macrotrends.https://www.macrotrends.net/1319/dow-jones-100-year-historical-chart

In financial markets there have been observed many unethical practices and behavior, like, (1) Scams, ${ }^{9}$ (2) Frauds, (3) Unfair trading practices, ${ }^{10}$ (4) Securities scams, ${ }^{11}$ (5) Churning, ${ }^{12}$ (6) Insider trading, ${ }^{13}$ (7) Window dressing, ${ }^{14}(8)$ Market manipulations,${ }^{15}$ etc. ${ }^{16}$ Without trust, fairness, and confidence, financial markets cannot function effectively and efficiently. Trust and integrity depend to an important degree on the reputation of financial markets to generate reliable valuations of companies and business undertakings and attempts. This perspective makes clear why the integrity of the management of the public trust must be accurate and reliable on correct information regarding publicly held companies and contributes to the appropriate functioning of financial markets. ${ }^{17}$ Also,

2020. A growth by $23,499.19$ points or $358.93 \%$ (30.76\% p.a.), which is an artificial wealth illusion. See, Figure 1 and Graph 4.

${ }^{9}$ See, "Common Scams and Frauds", https://www.usa.gov/common-scams-frauds\#item-36617

${ }^{10}$ See, https://openstax.org/books/business-law-i-essentials/pages/12-1-unfair-trade-practices

${ }^{11}$ See, "The Top 16 Types of Securities Fraud You Must Avoid", https://financialmentor.com/investmentadvice/investment-fraud-prevention/securities-fraud/18169

${ }^{12}$ Churning is the practice of executing trades for an investment account by a salesman or broker in order to generate commission from the account.

${ }_{13}^{13}$ Insider trading is the trading of a public company's stock or bonds or stock options based on material, nonpublic information about the company. Trading based on insider information is illegal. This is because it is seen as unfair to other investors who do not have access to the information, as the investor with insider information could potentially make larger profits than a typical investor could make. The rules governing insider trading are complex and the extent of enforcement difficult. The definition of insider can be broad, and may cover not only insiders themselves but also any persons related to them, such as brokers, associates, and even family members. Trading conducted by corporate officers, key employees, directors, or significant shareholders must be reported to the regulator or publicly disclosed, usually within a few business days of the trade. Insiders are required to file a Form 4 with the U.S. SEC when buying or selling shares of their own companies.

${ }^{14}$ Window dressing is a strategy used by mutual fund and other portfolio managers near the year or quarter end to improve the appearance of a fund's performance before presenting it to clients or shareholders. To window dress, the fund manager sells stocks with large losses and purchases high-flying stocks near the end of the quarter. These securities are then reported as part of the fund's holdings. See, https://www.investopedia.com/terms/w/windowdressing.asp

${ }^{15}$ Market manipulation is a type of market abuse (Insider dealing and Market manipulation), where a person knowingly gives out false or misleading information (for instance, about a company's financial circumstances) in order to influence the price of a share for personal gain where there is a deliberate attempt to interfere with the free and fair operation of the market and create artificial, false or misleading appearances with respect to the price of, or market for, a product, security, commodity or currency. See, Lin (2017). Market manipulation is prohibited in most countries, in particular, it is prohibited in the United States under Section 9(a)(2) of the Securities Exchange Act of 1934. See, "The Laws That Govern the Securities Industry",

https://www.sec.gov/answers/about-lawsshtml.html\#secexact1934.

${ }^{16}$ See, Hans (2020).

${ }^{17}$ Unfortunately, the "garbage in, garbage out" principle prevails in financial markets, public trust in the functioning of financial markets has declined as a result of major financial reporting scandals involving Enron, Tyco, WorldCom, Parmalat and others. See, Blommestein (2006). 
massive overvaluations of equity that occurred in the second half of the 1990s and in the early 2000s have been responsible for the dot-com crisis and had been caused by misinformation and manipulation of financial results. ${ }^{18}$ The same happened in 2007, 2015, 2018, 2019, and in 2020 by reaching, $D J I A=30,046.24(12 / 17 / 2020)$, with the different pseudo-euphoria (election results $\tau \tilde{\omega} v$

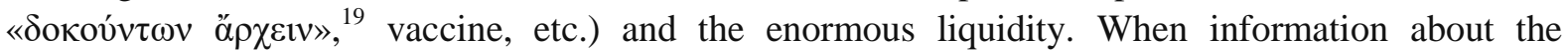
operation of public companies is false, misleading or not transparent, trust in financial markets is going to be affected adversely. This gives financial market participants a stake in the disclosure of timely and meaningful information, including by assuring that the quality of financial reporting by public companies is as high as possible. And this in turn puts the spotlight on the role of the gatekeepers ${ }^{20}$ of the public trust, in particular accounting firms, banks, rating agencies, supervisors, and regulators. ${ }^{21}$ But still the financial market remains very risky.

\section{EThits in PUblic Policies}

Public policy is the process by which governments (fiscal policy) and central banks (monetary policy) translate their political, ideological, and economic vision into programs and actions to deliver "outcomes, desired changes in the real world". The "real world" is the financial markets and institutions, businesses, households, and individuals, which is constantly changing and this has resulted in the movement towards greater use of evidence and experience in policy design, making and implementation, policy ethics, and Pareto optimality. ${ }^{22} \mathrm{We}$ have to focus on true scientific evidence, on full information (no fake news and propaganda or political expediency), on history and culture, which will guide public policy making for evaluating the contribution of any public policy.

Monetary policy and fiscal policy refer to the two most widely recognized tools of public policies, used to influence a nation's economic activity. ${ }^{23}$ Monetary policy is primarily concerned with the management of interest rates (target federal funds rate) and the total supply of money in circulation and it is carried out by the central bank (the Fed). Fiscal policy is a collective term for the taxing and spending actions of the government to improve the social welfare. In the United States, the national fiscal policy is determined by the executive and legislative branches of the government, but there are many political issues (unethical politics) and conflicts between the two parties (Republicans and Democrats), which avert its application. ${ }^{24}$


They may refuse, control or delay access to services. Alternatively, they may also be used to oversee how work is being done and whether it meets certain standards.

${ }^{21}$ See, Blommestein (2006).

${ }^{22}$ Pareto efficiency or Pareto optimality is a situation, where an individual or preference criterion can be better off without making at least one individual or preference criterion worse off. For example, the 2017 Tax Law is not Pareto Optimal because businesses are paying lower taxes, but some individuals higher than before. See, "Tax Cuts and Jobs Act of 2017”, https://en.wikipedia.org/wiki/Tax_Cuts_and_Jobs_Act_of_2017

${ }^{23}$ See, Troy Segal, "Monetary Policy vs. Fiscal Policy: What's the Difference?”,

https://www.investopedia.com/ask/answers/100314/whats-difference-between-monetary-policy-and-fiscalpolicy.asp

${ }^{24}$ These policies-politics have become the objective by the Democratic Party the last four years. They try with all the unethical means to go against the administration (the Republic party and the President). They tried to impeach the President starting with Russia, then Ukraine, impeachment, Coronavirus, economic crisis, riots, and they were working for a long time on what will be their next "tool", which was the 2020 election. Their supporters are the controlled Media with the fake news and propaganda, which intimidate people, the high tech companies. See, https://www.bbc.com/news/world-us-canada-50802150 . Also, "2019 CIGI-Ipsos Global Survey on Internet Security and Trust", https://www.cigionline.org/internet-survey-2019 . Further, The Mueller Report, officially titled Report on the Investigation into Russian Interference in the 2016 Presidential Election, is the official report documenting the findings and conclusions of former Special Counsel Robert Mueller's investigation into Russian efforts to interfere in the 2016 United States presidential election, allegations of conspiracy or coordination between Donald Trump's presidential campaign and Russia, and allegations of obstruction of justice. The report was submitted to Attorney General William Barr on March 22, 2019, and a redacted version of the 448-page report was publicly released by the Department of Justice (DOJ) on April 18, 2019. See,

https://www.foxnews.com/politics/muellers-report-on-russia-investigation-what-happened-dropped and 
Public problems that influence public policy making can be of different nature (financial, economic, social, political, international, recession, global, etc.), can originate in endless ways and require different policy responses (such as monetary, fiscal, currency devaluation, trade, sterilization, ${ }^{25}$ stimulus, regulations, subsidies, tariffs, import quotas, and laws) on the local, national, or international level. The private central bank and the government hold legal monopolies to initiate or threaten to impose their policies to achieve their ends when they think ("behove") it is necessary. For instance, in times of a deep recession and chaos, as it happened lately, with the coronavirus crisis, healthcare problems, the lockdown, and the stimulus package by the government ${ }^{26}$ and the zero interest rate by the $\mathrm{Fed},{ }^{27}$ when quick decision making was needed. They kept monopolies open and closed all the other small businesses. This is a completely unethical public policy.

Public policy making is an exhausting and time-consuming "policy cycle". Public policy must focus primarily on domestic policy, the welfare of the citizens of the country. The basic stages of policy cycle are as follows: a problem is identified, a policy response is formulated, the preferred solution is then selected and implemented, and finally the policy is evaluated. However, the evaluation stage must take an in depth look into what can be learnt from the process as a whole, whether the original problem has been solved, and if not, what is recommended as an alternative course of action or a follow up. Was this policy effective? Was the policy fair? Was the actions taken ethical? Was it Pareto optimal?

The U.S.A. has a very powerful central bank, which affects not only the domestic economy, but the other central banks around the world and the world's economies. Also, the country has a largely devolved government, with power at local, state and federal level. Due to these various levels of governance it can often be difficult to coordinate passing bills and legislation, and there is often disagreement between the two different philosophical believes parties (liberal and conservative). Despite this, the system allows for citizens to be relatively involved in inputting legislation because of their voting power (democracy), except in the U.S. during the last election. ${ }^{28}$ Furthermore, each level of government is set up in a similar way with similar rules, and all pump money (government spending) into creating what is hoped to be effective legislation. Policy creation in America is often seen as unique to other states, but the federal government is providing the same policy for all the 50 states. Some states or cities might oppose the central government policies for ideological reasons.

\subsection{Monetary Policy and Ethics}

The first major Fed's changes on 12/20/2008 altered the fed funds market in a number of astonishing ways: zero fed funds rate $\left(i_{\mathrm{FF}}=0.00 \%\right)$ for seven years, ${ }^{29}$ including the types of financial institutions that were trading, the rates at which they were borrowing and lending, and the new tools fabricated by the FOMC that could effectively influence these market rates. Nine months ago (3/20/2020), due to the coronavirus pandemic, Fed went back to zero interest rate. ${ }^{30}$ Because banks were overflowed with

https://www.politico.com/story/2019/04/18/mueller-report-pdf-download-text-file-1280891 . See also, The Voter Fraud in the 2020 Elections.. "A Sampling of Recent Election Fraud Cases from Across the United States"

https://www.heritage.org/voterfraud; https://www.heritage.org/voterfraud/search

${ }^{25}$ See, Kallianiotis (2019, pp. 52 and 71).

${ }^{26}$ President Donald Trump signed the Coronavirus Aid, Relief, and Economic Security Act, or CARES Act, into law; he initiated a \$2.4 trillion stimulus package, the largest emergency relief bill in American history. See, https://www.businessinsider.com/personal-finance/coronavirus-stimulus-check-questions-answers-2020-4 See also, "IRS stimulus check: What to know about your coronavirus payment, status, deadline", https://www.cnet.com/personal-finance/irs-stimulus-check-what-to-know-about-your-coronavirus-paymentstatus-deadline/ .

${ }^{27}$ On March 16, 2020, the FOMC made the target federal funds rate again zero: $0.00 \%<i_{F F}<0.25 \%$. https://www.federalreserve.gov/monetarypolicy/openmarket.htm and it increased the money supply from \$15.567 trillion (3/9/2020) to \$19.121 trillion (11/23/2020). https://fred.stlouisfed.org/series/M2

${ }^{28}$ President Trump said: "This election was a fraud, this election was rigged and it is hard to get the case to the Supreme Court." Fox News, 11/29/2020. But, nothing happened.

${ }_{29}$ See, "Federal Funds Target Range", https://fred.stlouisfed.org/series/DFEDTARU

${ }^{30}$ The Federal Reserve left the target range for its federal funds rate unchanged at $0-0.25$ percent on June 10th 2020 as expected. Policymakers reiterated they are committed to using a full range of tools to support the U.S. economy in this challenging time. The so-called dot plot of funds rate projections showed rates are expected to 
reserves, their desire to borrow effectively vanished, and bank-to-bank lending largely disappeared. ${ }^{31}$ However, once the Fed started paying interest on reserves ${ }^{32}$ to some (but not all) financial institutions, a new lending opportunity emerged. This Fed's anti-social "innovation" (paying interest of reserves) has kept the deposit rate closed to zero $\left(i_{D}=0.05 \%\right.$ ) for twelve years ${ }^{33}$ and because we are living in a free market economic system, banks charge an unethical (usurious) interest rate on credit cards of $39.99 \%$ and are paying another unethical rate of $0.05 \%$ on deposits. Kallianiotis (2017a) suggests different optimal interest rates for our economy. ${ }^{35}$

The Fed considers the required reserves as non-necessary monetary instrument and made them since March 26, 2020 zero $\left(R_{R}=0\right)$, also the federal funds rate zero $\left(i_{F F}=0.00 \%\right),{ }^{36}$ the effective federal

remain at current levels through 2022. Fed officials see the U.S. economy shrinking $6.5 \%$ in 2020 , compared to a $2 \%$ growth projected in December, but they see a 5\% growth in 2021 (vs $1.9 \%$ earlier forecasted). The unemployment rate is expected to rise to $9.3 \%$ this year (vs 3.5\%) and to fall to $6.5 \%$ in 2021 (vs $3.6 \%$ ). PCE inflation is seen slowing to $0.8 \%$ (vs $1.9 \%$ ) and rebounding to $1.6 \%$ in 2021 (vs $2 \%$ ). The Fed also said it will continue to increase its bond holdings, targeting Treasury purchases at $\$ 80$ billion a month and mortgagebacked securities at $\$ 40$ billion. https://tradingeconomics.com/united-states/interest-rate . Further, The official unemployment with October 2020 was $6.9 \%$ and the SGS gives the following values: May 2020 ShadowStats Alternate Unemployment is 34.0\%, 36.5\% net of BLS errors (Flash Nos. 1435 and 1439). In November 2020, the unemployment was $26.3 \%$. http://www.shadowstats.com/alternate_data/unemployment-charts and Consumer inflation- Official was $0.55 \%$ with October 2020 vs ShadowStats (1080-Based) Alternative with May 2020 was $8 \%$. The same it was in October 2020, 8\%. http://www.shadowstats.com/alternate_data/inflationcharts

${ }^{31}$ See, Key Features of the Federal Funds Market, Liberty Street Economics,

https://libertystreeteconomics.newyorkfed.org/2018/07/size-is-not-all-distribution-of-bank-reserves-and-fedfunds-dynamics/comments/ .

32 The Financial Services Regulatory Relief Act of 2006 authorized the Federal Reserve Banks to pay interest on balances held by or on behalf of depository institutions at Reserve Banks, subject to regulations of the Board of Governors, effective October 1, 2011. The effective date of this authority was advanced to October 1, 2008, by the Emergency Economic Stabilization Act of 2008.

${ }^{33}$ See, https://www.valuepenguin.com/banking/average-bank-interest-rates

${ }^{34}$ This unreasonable, unethical, outrageous, and usurious interest rate is charged for the poor people by the unregulated and corrupted banks. Is this a social policy or a deception? The following statement is from one of my graduate students' answer for the following question: Is the Risk Premium on our credit cards justifiable?

"This is my ethical perspective on Risk Premium on credit cards. While pursuing my undergraduate degree, I worked for one of the most corrupt credit card companies. It is a sub-prime credit card company that preyed on vulnerable people with bad or no credit. The card would be sent out to consumers with $\$ 198$ in processing fees with a $\$ 250$ credit line. People did not read the small printed brochures and people would just activate these cards. People would use these credit cards and not realize that they only had $\$ 52$ to spend. At that point the card would be maxed out and the company began charging over limit fees of $\$ 30$ and an interest rate of $29.99 \%$. Soon this was followed by $\$ 35$ late fees. I do not believe that a high Risk Premium is morally justifiable. I was the representative on the other end of the phone who listened to story after story. For example, an elderly person who purchased a prescription because he/she needed it; a young mother who put gas in her car; a disabled person who did not understand how the credit card worked. These were vulnerable people who were taken advantage of by a greedy, avaricious company. This credit card company did more than mitigate their risks. The company preyed on poor, uneducated people. As a side note, the owner of this company last year received an award for philanthropist of the year. This puts a real spin on what Americans views as value. This is an ethical/moral perspective on the horrors of unchecked free market capitalism." [K. L. (FIN 508) Summer 2013].

Note: In the U.S., the risk premium can reach the level of: $\mathrm{RP}=40 \%$ (a regressive tax on the poor). In EU, there is a cap on credit cards risk premium of: $\mathrm{RP}=15 \%$.

${ }^{35}$ The optimal interest rate on deposits (savings accounts) must be: $i_{D_{t}}^{*}=\pi_{t}^{e}+1 \%$ and the optimal interest rate on loans (the highest) must be: $i_{L_{t}}^{*}=i_{P_{t}}+5 \%$, where $i_{D}^{*}=$ the optimal deposit rate, $\pi^{e}=$ expected true inflation rate, $i_{L}^{*}=$ the optimal loan rate, and $i_{P}=$ the prime rate.

${ }^{36}$ Global and U.S. bank stocks fell Thursday (6/11/2020); DJIA lost 1,861.82 points (-6.9\%) to 25,128.17, a day after Fed officials indicated they had no plans to raise interest rates over the next two years. Shares of JPMorgan Chase JPM -8.34\% \& Co., Bank of America Corp. and Wells Fargo WFC -9.83\% \& Co. and Citigroup Inc. C - 
funds rate with May 2020 was $i_{F F}^{e f f}=0.05 \%$, and the discount rate $\left(i_{D R}=0.25 \%\right)$, Graph $1 .{ }^{37}$ This means that it abandoned the reserve requirement ratio $\left(r_{R}=0.00 \%\right)$, as a monetary policy tool. ${ }^{38}$ This is a new major bank deregulation, which is very risky for the financial institutions and the economy (the people). The Fed has substituted the required reserves with the excess reserves by supplying them in trillions of dollars $R_{E}=\$ 3.218$ trillion (May 2020). The interest on reserves that Fed is paying to the banks is now $\left(i_{I O R}=0.10 \%\right),{ }^{39}$ Graph 2 . The 3-month T-Bill rate $(6 / 9 / 2020)$ was $i_{R F}=0.19 \%$ and in the secondary market, $i_{R F}=0.10 \%$; in November 2020, it became $i_{R F}=0.09 \%$. ${ }^{40}$ Money is free, due to its excess supply; ${ }^{41}$ but is this monetary policy effective, fair, ethical, and riskless? The first

$13.37 \%$ fell between $5 \%$ and $7 \%$ early Thursday. Fed officials indicated that short-term rates would likely remain near zero through 2022, citing the coronavirus pandemic's potential to do long-term damage to the U.S. economy and a yearlong labor-market recovery. "We're not thinking about raising rates. We're not even thinking about raising rates," said Fed Chairman Jerome Powell. See, "Bank Stocks Fall After Fed Projects No Rate Increases", https://www.wsj.com/articles/bank-stocks-fall-after-fed-projects-no-rate-increases-1159189 1477?mod=md_usstk_news

${ }^{37}$ Graph 1: Discount Rate for United States:

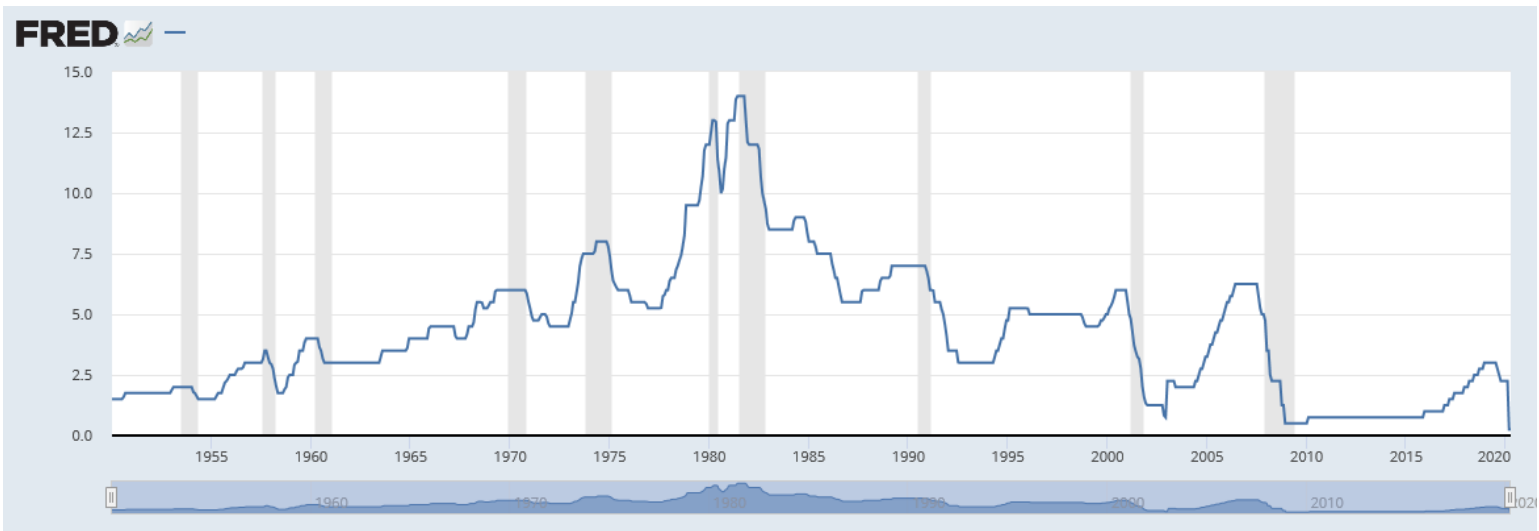

Source: https://fred.stlouisfed.org/series/INTDSRUSM193N

${ }^{38} \mathrm{See}$, "Fed sets $0 \%$ reserve requirement ratio, urges banks to use capital, liquidity buffers to bolster lending in face of coronavirus". https://www.regreport.info/2020/03/15/fed-sets-0-reserve-requirement-ratio-urges-banksto-use-capital-liquidity-buffers-to-bolster-lending-in-face-of-coronavirus/ . The reserve requirements started on December 23, 1913 and were abolished on March 26, 2020. See also,

https://www.federalreserve.gov/newsevents/pressreleases/monetary20200315b.htm

${ }^{39}$ Graph 2: Interest Rate on Excess Reserves

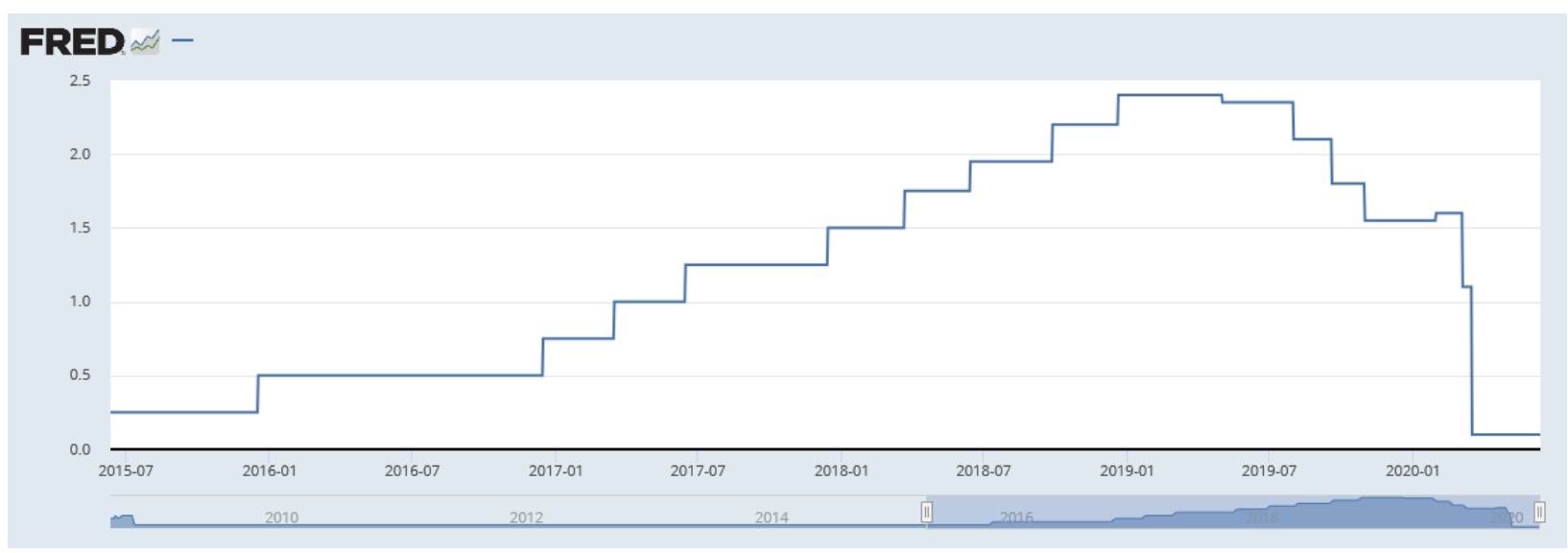

Source: https://fred.stlouisfed.org/series/IOER

${ }^{40}$ See, 3-month Treasury Bills - Secondary Market. http://economagic.com/em-cgi/data.exe/fedbog/tbsm3m

${ }^{41}$ With June 1,2020 , the M2 was $\$ 18.153$ trillion and with November 23, it became $\$ 19.121$ trillion. With 2020:Q1, the GDP was $\$ 18.975$ trillion and with 2020:Q3, it was $\$ 18.584$ trillion.. (Economagic.com). This means velocity close to zero and inflation very high. 
perspective of required reserves concerns risk. Is the zero reserve requirement ratio riskless? The reason banks hold reserves is in case that synchronization ${ }^{42}$ fails. If synchronization exists, the bank does not need to hold a lot in reserves; it can take the money that someone has deposited and give it to the other person, when he comes in to make a withdrawal. This allows the bank to devote the bulk of its funds to long-term investments that pay high rates in interest.

However, if on a particular day, the demand for withdrawals from the bank is increasing, the bank has to scramble to come up with cash from its reserves. But, if it does not have the reserves, the bank finds itself in trouble. When one bank finds itself having to shut its doors because it cannot meet the demand for liquidity, customers of all the other banks get scared that their bank might be in the same position. Then, the whole banking system, which depends on the depositors' confidence, is under siege (run on the bank). ${ }^{43}$ Another problem can be the stability of monetary policy. What the Federal Reserve wants, it is to create a steady demand for reserves so that it can provide more reserves (by reducing the $r_{R}$ ) when it wants to allow banks to create more loans, and increase the money supply, and provide fewer reserves when it wants to put banks in the position of having to call in loans and shrink the money supply (tight money). By creating a mandatory reserve requirement, the Fed creates a stable demand for reserves, which allows it then to manipulate the money supply with some regularity and security. Now, these perspectives have been lost.

If we allow banks to decide by themselves (another deregulation) how much they want to hold as reserves, they are going to hold the amount of reserves that minimizes the risk of not having money to give their depositors when they ask for withdrawals. The question is now. Is it good to let the market solve social economic problems rather, than regulators with their law? Banks maximize their objective ignoring the risk because the government will bail them out, as it happened in 2008 that cost to the taxpayers trillions of dollars. The government passaged into U.S. law, on October 3, 2008, a $\$ 700$ billion financial-sector rescue plan that was the latest in the long history of U.S. government bailouts. The 2020 COVID-19 pandemic led to multi-trillion dollar bailouts of both businesses and individuals in America and similar policies have been taken across the globe. To date, nearly $\$ 4$ trillion has been deployed to keep the economy running in the face of this suspicious Chinese pandemic, the Wuhan coronavirus. ${ }^{44}$ Regulators (Fed, FDIC, etc. ) must concern about the systemic nature of risk in the banking system and should fear about policy, which is not being conducted in an orderly and reliable way, meaning that reserve requirements should exist to control $\mathrm{MB}$ and $\mathrm{M}^{\mathrm{s}}$ (Graphs 3 and 4 ), ${ }^{45}$ together with higher margin requirements (since 1974, it is $\left.r_{m}=50 \%\right)^{46}$ and many other regulations.

\footnotetext{
${ }^{42}$ Synchronization means that on a given day, people are depositing about as much money as they are withdrawing.

${ }^{43}$ A bank run (also known as a run on the bank) occurs when many depositors withdraw their money from a bank, because they believe the bank may cease to function in the near future. In other words, it is when, in a fractional-reserve banking (or zero reserves, today) system (where banks normally only were keeping a small proportion of their assets as cash, $r_{R}=10 \%$ ), numerous depositors withdraw cash from their deposit accounts with a financial institution at the same time because they believe that the financial institution is, or might become, insolvent. See, https://en.wikipedia.org/wiki/Bank_run

${ }^{44}$ See, "US Government Financial Bailouts", https://www.investopedia.com/articles/economics/08/governmentfinancial-bailout.asp . Also, "Emergency Economic Stabilization Act of 2008",

https://en.wikipedia.org/wiki/Emergency_Economic_Stabilization_Act_of_2008 . Further, "Here's what's in the $\$ 2$ trillion stimulus package — and what's next", https://www.politico.com/news/2020/03/25/whats-in-stimuluspackage-coronavirus-149282 . A Chinese virologist, Dr. Li-Meng Yan said: "This virus came from a Wuhan Lab and it was intentional." (Fox News, 11/20/2020).

${ }^{45}$ See,

file:///C:/Users/JK/AppData/Local/Microsoft/Windows/Temporary\%20Internet\%20Files/Content.IE5/51F9Y8A K/8517.pdf

Graph 3: The monetary base (MB).
}

It became $\$ 5.150$ trillion with May 2020 . 
As it was mentioned and it is known to every saver, the deposit rate is closed to zero $\left(i_{D}=0.05 \%\right)$ since December 2008, more than twelve years. This negative real deposit rate is completely unethical and unfair for the depositors, who pay interest to the banks for keeping their deposits (bail in). ${ }^{47}$ With an inflation of $\pi=7 \%$ for May $2020,{ }^{48}$ the $r_{D}=-6.95 \%$, which is the amount paid to the banks. ${ }^{49}$ Also, these unethical policies have a negative effect on demand for deposits and force risk-averse individuals to invest in risky financial assets (stocks, Figure 1) to have a positive real return; but banks do not need deposits, they have all these strange excess reserves from the Fed. ${ }^{50}$ Deposits had declined in the U.S. banks (Graph 5). ${ }^{51}$ "Now, however, the average savings

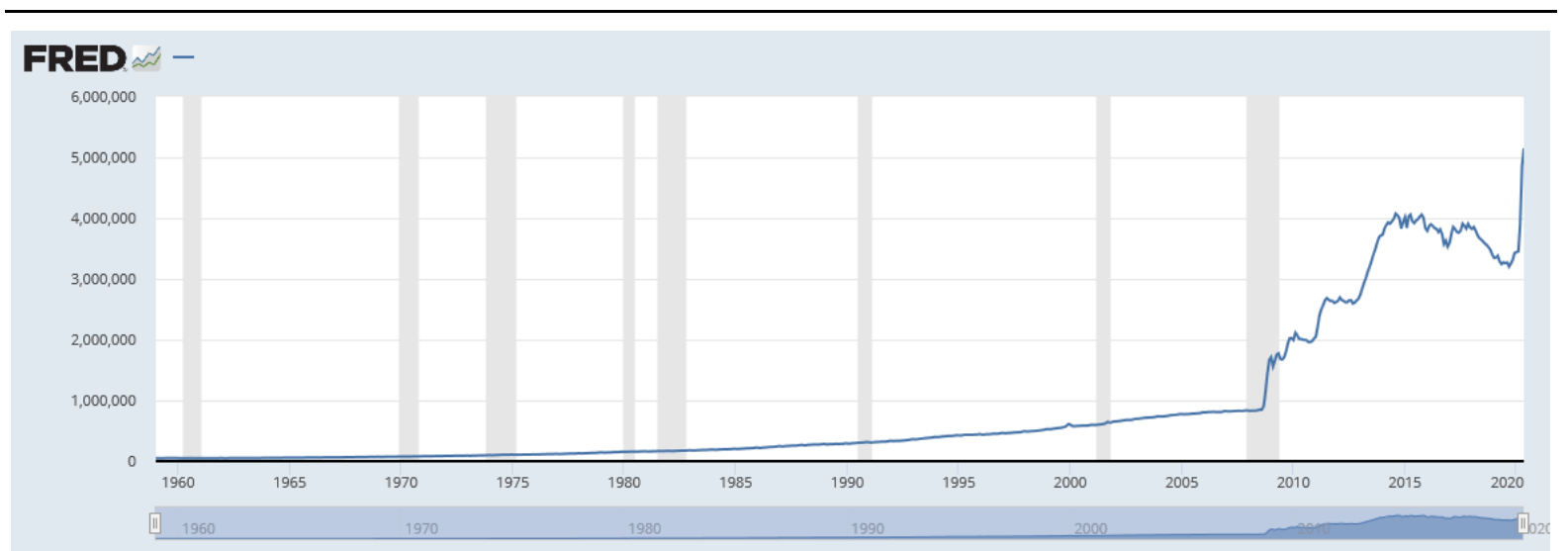

Source: https://fred.stlouisfed.org/series/BOGMBASE

Graph 4: The money supply $\left(\mathrm{M}^{\mathrm{s}}\right)$.

It was $\$ 18.115$ trillion, with May 2020 .

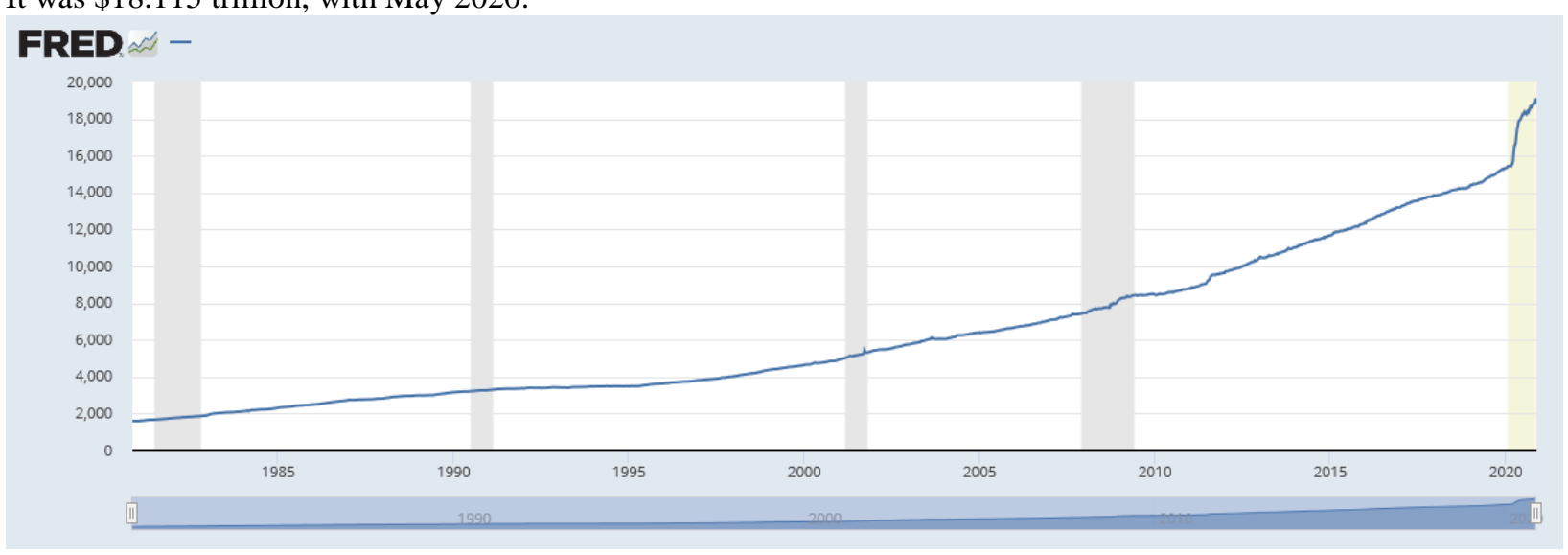

Source: https://fred.stlouisfed.org/series/M2

${ }^{46}$ See, "Margin Requirements as a Policy Tool?", https://www.frbsf.org/economic-

research/publications/economic-letter/2000/march/margin-requirements-as-a-policy-tool/

${ }^{47}$ So far this kind of policy existed only in money (tax) havens, where they were accepted illegal money and were helping the depositors to avoid taxes back home, like Switzerland and other offshore centers. Now, we have these structures locally; we became Switzerland. See,

file:///C:/Users/JK/AppData/Local/Microsoft/Windows/Temporary\%20Internet\%20Files/Content.IE5/QSJRY92 C/Corporate-Tax-Dodgers-Report-Final.pdf

${ }^{48}$ See, $S G S$, http://www.shadowstats.com/alternate_data/inflation-charts

${ }^{49}$ The interest rate must be positive and above the inflation rate. Even the Bible is talking about positive interest

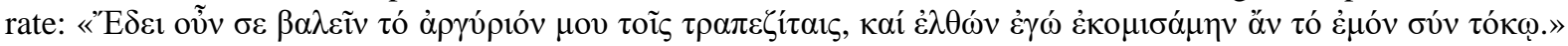
("Then you ought to have invested my money with the bankers, and on my return I would have received what was my own with interest".). Matthew 25: 27.

${ }^{50}$ Excess Reserves have jumped to $\$ 3.218$ trillion with May 2020. See,

https://fred.stlouisfed.org/series/EXCSRESNS

The required reserves became $\$ 0.000$. This action eliminated reserve requirements for all depository institutions. https://www.federalreserve.gov/monetarypolicy/reservereq.htm . See also,

https://fred.stlouisfed.org/series/REQRESNS . "Recently, the Federal Reserve announced they were reducing the reserve requirement ratio to zero percent across all deposit tiers, effective March 26, 2020. This comes as the COVID-19 pandemic continues to impact much of the way financial institutions both operate and serve their customers." 
account pays only $0.10 \%$ annually - that's one-tenth of $1 \%$ - and many of the country's biggest banks pay less than that. If you were to put \$5,000 in a regular Bank of America savings account (paying $0.01 \%$ ) today, in a year you would have collected only 50 cents in interest. That's true for most of us, but banks themselves are earning $2.4 \%$ on their deposits at the Federal Reserve. These deposits, called 'excess reserves', include the reserves the banks got from our deposits, and on which they are paying almost nothing; and unlike with our deposits, there is no $\$ 250,000$ cap on the sums banks can stash at the Fed amassing interest. A whopping $\$ 1.5$ trillion in reserves are now sitting in Fed reserve accounts. [\$3.218 trillion with May 2020 and \$2.877 trillion in October 2020]. The Fed rebates its profits to the government after deducting its costs, and interest paid to banks is one of those costs. That means we, the taxpayers, are paying \$36 billion annually to private banks for the privilege of parking their excess reserves at one of the most secure banks in the world-parking them, rather than lending them out." 52

This policy tool is, if not anything else, an unethical policy against small savers (investors) and poor taxpayers. Political leaders must have some influence on these "independent", corrupted and externally controlled private central banks. Their policies are ineffective for the economy, nonpreventable for a new financial crisis, and anti-social for the people. Especially, now, with the suspicious coronavirus the necessary policy is mostly a fiscal stimulus policy that the government provided ${ }^{53}$ but, at the current election crisis, fiscal policy is stagnated. The latest monetary policies benefit only large banks, ${ }^{54}$ as follows:

(a) With December 2019, we had:

(Ia) The total reserves $\left(\mathrm{R}_{\mathrm{T}}\right)$ were: $R_{R}=\$ 206.586$ billion $+R_{E}=\$ 1,388.636$ billion $=R_{T}=$

$\$ 1,595.222$ billion.

The interest on reserves was: $i_{I O R}=i_{R F}+0.20 \%=1.52 \%+0.20 \%=1.72 \%$.

Thus, Fed was paying total interest on these reserves $\left(I_{R}\right)=\$ 1,595.222$ billion $\times 1.72 \%=$ $\$ \mathbf{2 7 . 4 3 8}$ billion per annum. This is a bail out cost that taxpayers are paying. ${ }^{55}$

https://www.eidebailly.com/insights/articles/2020/4/federal-reserve-eliminates-reserve-requirements Thus, the total reserves are equal to the excess reserves: $\$ 3.218$ trillion. See, https://fred.stlouisfed.org/series/TOTRESNS

${ }^{51}$ Graph 6: Deposits, All Commercial Banks

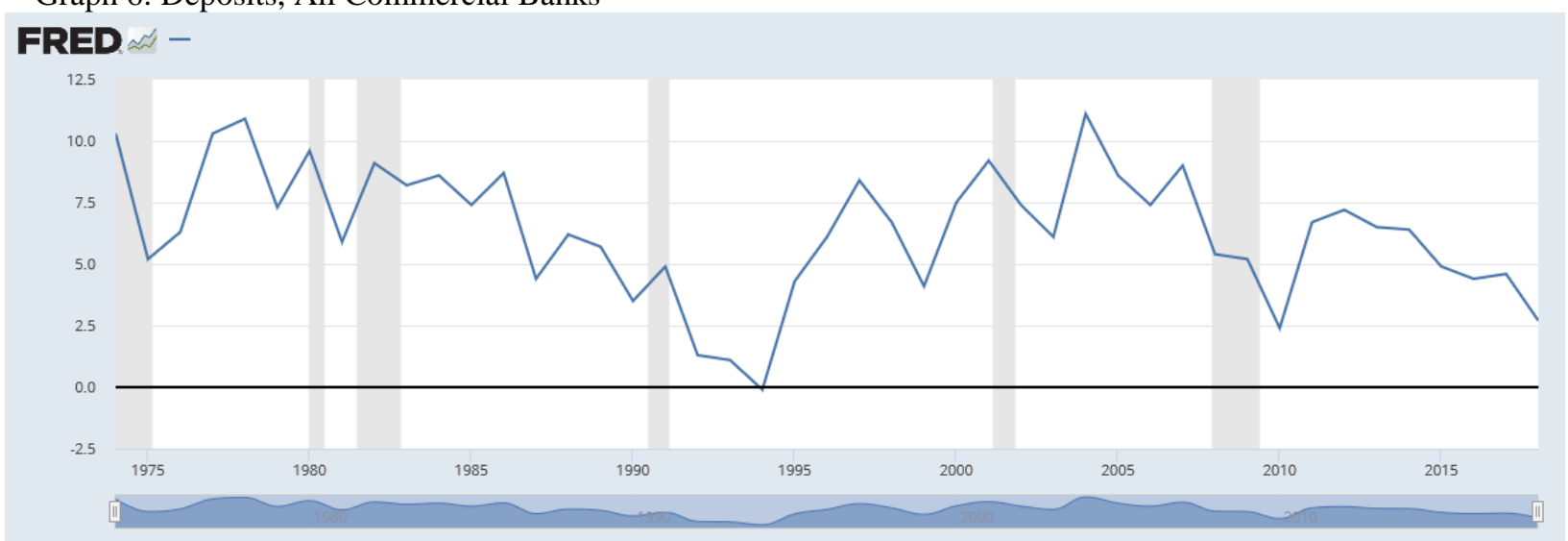

Source: https://fred.stlouisfed.org/series/H8B1058NCBCAG

${ }^{52}$ See, Ellen Brown, "Why Is the Fed Paying So Much Interest to Banks?", https://www.truthdig.com/articles/why-is-thefed-paying-so-much-interest-to-banks/. See also, "2.4\%, Why Is the Fed Paying So Much Higher Interest Rate to Banks?", https://www.econmatters.com/2019/04/24-why-is-fed-paying-so-much-higher.html

${ }^{53}$ See, "Fiscal Stimulus Needed to Fight Recessions", https://www.cbpp.org/research/economy/fiscal-stimulusneeded-to-fight-recessions

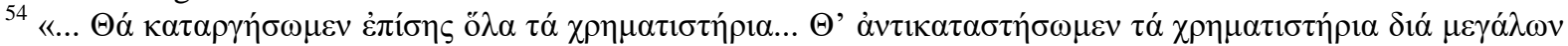

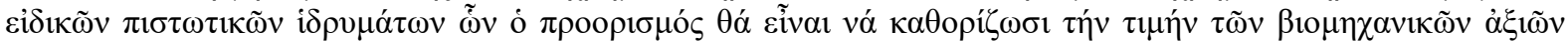

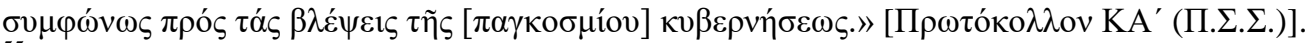

${ }^{55}$ Federal Reserve Unfunded interest since 1913 is $\$ 10.772$ trillion and now it is $\$ 527.214$ billion. See, https://usdebtclock.org/ 
(IIa)Total deposits $\left(D_{T}\right)=D_{S}=\$ 9,801.1$ billion $+D_{S-D T D}=\$ 588.7$ billion $=\$ 10,389.8$ billion.$^{56}$

The $i_{D}=0.05 \%$

Banks were paying an insignificant total interest on deposits $\left(I_{D}\right)=\$ 10,389.8$ billion $\mathrm{x}$ $0.05 \%=\$ \mathbf{5 . 1 9 5}$ billion per annum.

(IIIa) The official inflation rate was $(\pi)=2.3 \%$; then, $r_{D}=i_{D}-\pi=0.05 \%-2.3 \%=-2.25 \%$

Thus, depositors were paying to their banks (bail in): $\$ 10,389.8 \times(-2.25 \%)=\$ 233.771$ billion.

The SGS consumer inflation (1980-based) ${ }^{57}$ was $\pi=10 \%$.

The true bail in was: $\$ 10,389.8 \times(-9.95 \%)=\$ \mathbf{\$ 1 , 0 3 3 . 7 8 5}$ billion p.a.

(IVa) Banks could offer loans: $R_{E}+D_{T}=\$ 1,388.638$ billion $+\$ 10,389.8$ billion $=\$ 11,778.438$

billion.

Banks' interest rate was from 3\% (mortgage rate) to $39.99 \%$ (credit cards with bad credit scores). ${ }^{58}$ The average $i_{C C}=19 \% .{ }^{59}$ Then, the average loan rate was: $\bar{i}_{L}=(3 \%+19 \%): 2=$ $11 \%$.

Banks were having an interest revenue $\left(R_{I}\right)$ of $\$ 11,778.438$ billion $x 11 \%=\$ \mathbf{1 1 , 2 9 5 . 6 2 8}$ billion p.a. ${ }^{60}$

The conclusion, here, is obvious, the central bank is working for the banks and satisfies only their objectives, which are profitability and liquidity. This monetary policy is against poor depositors (bail in cost $=\$ 1.033 .785$ trillion p.a. or the "official" bail in cost $=\$ 233.771$ billion) and poor taxpayers (bail out cost $=\$ 27.438$ billion p.a.), a pure anti-social policy and at the same time it had created enormous bubbles in the stock market, Figure 1 (a hidden new global crisis, which found an excuse to burst, the Wuhan coronavirus). ${ }^{61}$ With this unethical monetary policy, the deposit and saving rate is falling (Graph 5 and Figures 2 and 3) and the personal consumption expenditures are increasing (Graph 7 and Figures 3 and 4). Thus, the household debt is going up. ${ }^{62}$

(b) With May 2020, we had the following bail out and bail in cost:

(Ib) The total reserves were: $\$ 3,217.635$ billion.

The $i_{\text {IOR }}=i_{R F}+0.20 \%=0.10 \%+0.20 \%=0.30 \%$.

Thus, Fed is paying total interest on these reserves $\left(I_{R}\right)=\$ 3,217.635$ billion $\times 0.30 \%=$ $\$ \mathbf{9 . 6 5 3}$ billion per annum. This is the current bail out cost that taxpayers are paying.

(IIb) Total deposits $\left(D_{T}\right)=\$ 15,470.758$ billion.

The $i_{D}=0.05 \%$

Banks are paying an insignificant total interest on deposits $\left(I_{D}\right)=\$ 15,470.758$ billion $\mathrm{x}$ $0.05 \%=\$ 7.735$ billion per annum.

\footnotetext{
${ }^{56}$ See, Economagic.com

${ }^{57} \mathrm{See}, \mathrm{SGS}$, http://www.shadowstats.com/alternate_data/inflation-charts

${ }^{58} \mathrm{See}$, https://www.economicshelp.org/blog/6775/debt/total-us-debt-public-private/ See also, https://usdebtclock.org/

${ }^{59}$ See, https://wallethub.com/answers/cc/highest-credit-card-interest-rate-2140660307/

${ }^{60}$ See, Kallianiotis (2020c, p. 66).

${ }^{61}$ The DJIA reached 29,551.42 (2/12/2020) and with coronavirus negative effects on health and economy, it fell to $18,591.93(3 / 23 / 2020)$, it lost $10,959.49$ points $(-37.09 \%)$. I had read somewhere a few years ago that: "we (the economic elites) will abolish the stock exchanges and we will create large financial institutions..." (Sic).

62 The total personal debt is $\$ 20.912$ trillion $\times 11 \%=\$ 2.3$ trillion annual interest on personal debt. See, https://usdebtclock.org/ . Actually, the average person is paying taxes, interest, and insurance premium; the rest of his income is consumed. For this reason his saving is negative (dissaving, borrowing).
} 
(IIIb) The official inflation rate is $(\pi)=0.10 \%$; then, $r_{D}=i_{D}-\pi=0.05 \%-0.10 \%=-0.05 \%$

Thus, depositors are paying to their banks (bail in): $\$ 15,470.758 \times(-0.05 \%)=\$ \mathbf{7 . 7 3 5}$ billion per annum.

The SGS consumer inflation (1980-based ${ }^{63}$ is $\pi=7 \%$.

The true bail in is now: $\$ 15,470.758 \times(-6.95 \%)=\mathbf{\$ 1 , 0 7 5 . 2 1 8}$ billion p.a.

(IVb) Banks could offer loans: $\mathrm{R}_{\mathrm{T}}+\mathrm{D}_{\mathrm{T}}=\$ 3,217.635+\$ 15,470.758=\$ 18,688.393$ billion.

Interest revenue $\left(\mathrm{R}_{\mathrm{I}}\right)$ : $\$ 18,688.393$ x $11 \%=\$ 2,055.723$ billion p.a.

(c) With December 2020, we have:

(Ic) The total reserves were: $\$ 2,876.6$ billion.

The $i_{I O R}=i_{R F}+0.20 \%=0.09 \%+0.20 \%=0.29 \%$.

Thus, Fed is paying total interest on these reserves $\left(I_{R}\right)=\$ 2,876.6$ billion $\times 0.29 \%=$ $\mathbf{\$ 8 . 3 4 2}$ billion per annum. This is the current bail out cost that taxpayers are paying.

(IIc) Total deposits $\left(D_{T}\right)=\$ 16,057.7016$ billion.

The $i_{D}=0.05 \%$

Banks are paying an insignificant total interest on deposits $\left(I_{D}\right)=\$ 16,057.7016$ billion $\mathrm{x}$ $0.05 \%=\$ \mathbf{8 . 0 2 9}$ billion per annum.

(IIIc) The official inflation rate is $(\pi)=1.2 \%$; then, $r_{D}=i_{D}-\pi=0.05 \%-1.2 \%=-1.15 \%$

Thus, depositors are paying to their banks (bail in): $\$ 16,057.7016 \times(-1.15 \%)=\$ \mathbf{1 8 4 . 6 6 4}$ billion per annum.

The SGS consumer inflation (1980-based) ${ }^{64}$ is $\pi=7 \%$.

The true bail in is now: $\$ 16,057.7016 \times(-6.95 \%)=\$ \mathbf{1 , 1 1 6 . 0 1 0}$ billion p.a.

(IVc) Banks could offer loans: $\mathrm{R}_{\mathrm{T}}+\mathrm{D}_{\mathrm{T}}=\$ 2,876.6+\$ 16,057.7016=\$ 18,934.301$ billion.

Interest revenue $\left(\mathrm{R}_{\mathrm{I}}\right): \$ 18,934.301 \times 11 \%=\$ 2,082.773$ billion p.a.

Thus, the unfair policy is going on and shows that the lack of ethics in monetary policy continues and taxpayers and depositors are ripped off for more than twelve years.

The Fed's current balance sheet is so huge (it was $\$ 4,175.850$ billion with January 15,2020 , with June $10,2020$ it had reached $\$ 7,168.936$ billion, and now, December 2,2020 it is $\$ 7.222 .414$ billion $)^{65}$ that with the new announced policy rate decrease (March 15, 2020), it could possibly generate surprising results and higher market risk. Some improvement to the bail out cost (taxpayers), due to lower interest rate on reserves exists, but deterioration to the bail in cost (depositors) has been attained. The level of banks' capital is another factor that must be considered by the regulators (central bank, FDIC, comptroller of the currency, etc.). A low capital level is increasing the risk of the bank and the cost of financial crises (by bailing them out in case of a financial crisis); so the bank capital affects the real economy. Risk-averse consumers prefer higher capital levels because it increases the financial stability in the economy and the world. The tax-payers cannot bailout the corrupted and deregulated financial institutions in case of a new bank crisis, as it happened in 2008 because it is completely unethical. ${ }^{66}$ Firestone, Lorenc, and Ranish (2019), by evaluating the economic costs and benefits of

\footnotetext{
${ }^{63}$ See, SGS. http://www.shadowstats.com/alternate_data/inflation-charts

${ }^{64}$ See, SGS. http://www.shadowstats.com/alternate_data/inflation-charts

${ }^{65} \mathrm{See}, \mathrm{https}$ ://fred.stlouisfed.org/series/WALCL

${ }^{66}$ The total lost household wealth at that time was between $\$ 19.2$ and $\$ 22$ trillion. See, https://www.pbs.org/wgbh/frontline/article/how-much-did-the-financial-crisis-cost/ and https://www.huffpost.com/entry/financial-crisis-cost-gao_n_2687553 . See also, "I helped bail out the banks,
} 
bank capital in the U.S., found that the optimal capital ratio is from just over $13 \%$ to $26 \%{ }^{67}$ The current average capital ratio is $12.5 \%$ for the U.S. banks, which is relatively low.

Impudently and very often, lately, in the U.S. and in Europe, the central bankers remind to politician and to the public that they are independent (from whom? from the citizens?). (Sic). But, their objective must be the social wellbeing of the citizens. The former heads of the Federal Reserve made their case, on August 5, 2019, for the central bank to remain independent and free from short-term political pressures, ${ }^{68}$ an implicit rebuttal to President Trump's repeated criticism of this private institution, the Fed. All four former still-living Fed chairs-Paul Volcker, ${ }^{69}$ Alan Greenspan, Ben Bernanke and Janet Yellen ${ }^{70}$ - consigned an op-ed ${ }^{71}$ underlining their belief that the central bank and its leader should be allowed to serve without political pressures or "the threat of removal or demotion... for political reasons". "It is critical to preserve the Federal Reserve's ability to make decisions based on the best interests of the nation, not the interests of a small group of politicians," the former central bankers wrote. ${ }^{72}$ This rhetoric is very good, but what we see so far, it is that Fed's policies are made only for the speculative financial market, its participants, and for the corrupted financial institutions. Their effects on the real economy are insignificant and many times negative by creating bubbles and accomplishing the next recession. If the central bank's decisions were based on the best interest of the nation, it would have a policy to prevent financial crises and recessions and not to try to cure them, after their creation. Federal Reserve Chairman Jerome Powell gave his most forceful warning yet (on August 23, 2019) about the risks to the U.S. economy from escalating trade tensions and the limits to the central bank's ability to cushion any fallout. (Sic). The trade deficit has to become zero ( $T A \cong 0$ ), so the country can become self-sufficient and not dependent on foreign production, which is very risky, as we saw with the medical supplies and the medicine during the coronavirus pandemic, which are coming from China. China is in control of our economy and it tries to control our politics, too. He signaled that the central bank would follow its rate cut of July 31

Congress needs to oversee the stimulus now", https://thehill.com/blogs/congress-blog/politics/496307-i-helpedbail-out-the-banks-congress-needs-to-oversee-the

67 See, Firestone, Lorenc, and Ranish (2019). See also, Farla-e-Castro (2019). Further, "What's a Countercyclical Capital Buffer?”, https://fredblog.stlouisfed.org/2019/09/whats-a-countercyclical-capital-buffer/

${ }^{68}$ But, President Woodrow Wilson had said that the U.S. lost control of its financial system by allowing its Central Bank to be independent of the government (private): "I am a most unhappy man. I have unwittingly ruined my country. A great industrial nation is controlled by its system of credit. Our system of credit is concentrated. The growth of the nation, therefore, and all our activities are in the hands of a few men. We have come to be one of the worst ruled, one of the most completely controlled and dominated Governments in the civilized world -- no longer a Government by free opinion, no longer a Government by conviction and the vote of the majority, but a Government by the opinion and duress of a small group of dominant men." [Woodrow Wilson President of the United States (1913-1921)]. What can we say 105 years later, where individual liberties and freedom have been lost? With the 2020 election irregularities, President Trump said: "We are like third world country; this election was a fraud." (Fox News, 11/26/2020).

${ }^{69}$ Paul Volcker passed away on December 8, 2019. https://www.sgtreport.com/2019/12/former-fed-chairmanpaul-volcker-passes-away-at-92/

${ }^{70}$ Joe Biden appointed Janet Yellen as Treasury Secretary. (ABC News, 11/23/2020).

${ }^{71}$ See, "America Needs an Independent Fed", The economy functions best when the central bank is free of short-term political pressures, The Wall Street Journal, https:/www.wsj.com/articles/america-needs-anindependent-fed-11565045308?mod=article_inline

72 See, "Former Fed Leaders Plea for Central Bank's Political Independence".

https://www.wsj.com/articles/former-fed-leaders-plea-for-central-banks-political-independence-11565051192 Unfortunately, "Our money is not our money. We rent it. We have rented it since 1781 when the Bank of North America gained control of the money supply in the closing days of the Revolutionary War. We need to own our money as citizens responsible for both the government and the economy of the United States." See, Bob Blain, The Root of United States Public and Private Debt, 2017. Also, "Permit me to issue and control the money supply of a nation and I care not who makes its laws." (Mayer Amschel Rothschild, 1744-1812). Further, "The privilege of creating and issuing money is not only the supreme prerogative of Government, but it is the Government's greatest creative opportunity." (Abraham Lincoln, 1862). In addition, "Until the control of the issue of currency and credit is restored to government and recognized as its most conspicuous and sacred responsibility, all talks of the sovereignty of Parliament and of democracy is idle and futile." (William Lyon Mackenzie King, Canadian Prime Minister, 1874-1950). For what ethics are we talking? 
$2019 .{ }^{73}$ On January 29,2020 , the FOMC decided to keep the federal funds at the same level; but the Apocalyptic Plague (coronavirus) forced the Fed to reduce the target rate back to zero ${ }^{74}$ (March 16, 2020).

Furthermore, another proof, showing the control (by the economic elites) of the central banks, is coming from U.K. The globalists of the Bank of England are against the Brexit, which is against the referendum of the people (it acts anti-democratically) and tried to terrorize the British citizens and to keep them inside the EU by saying: "if they will leave the EU, there will be a global disaster" ${ }^{75}$ How can we trust the central bankers, who do not believe in democracy

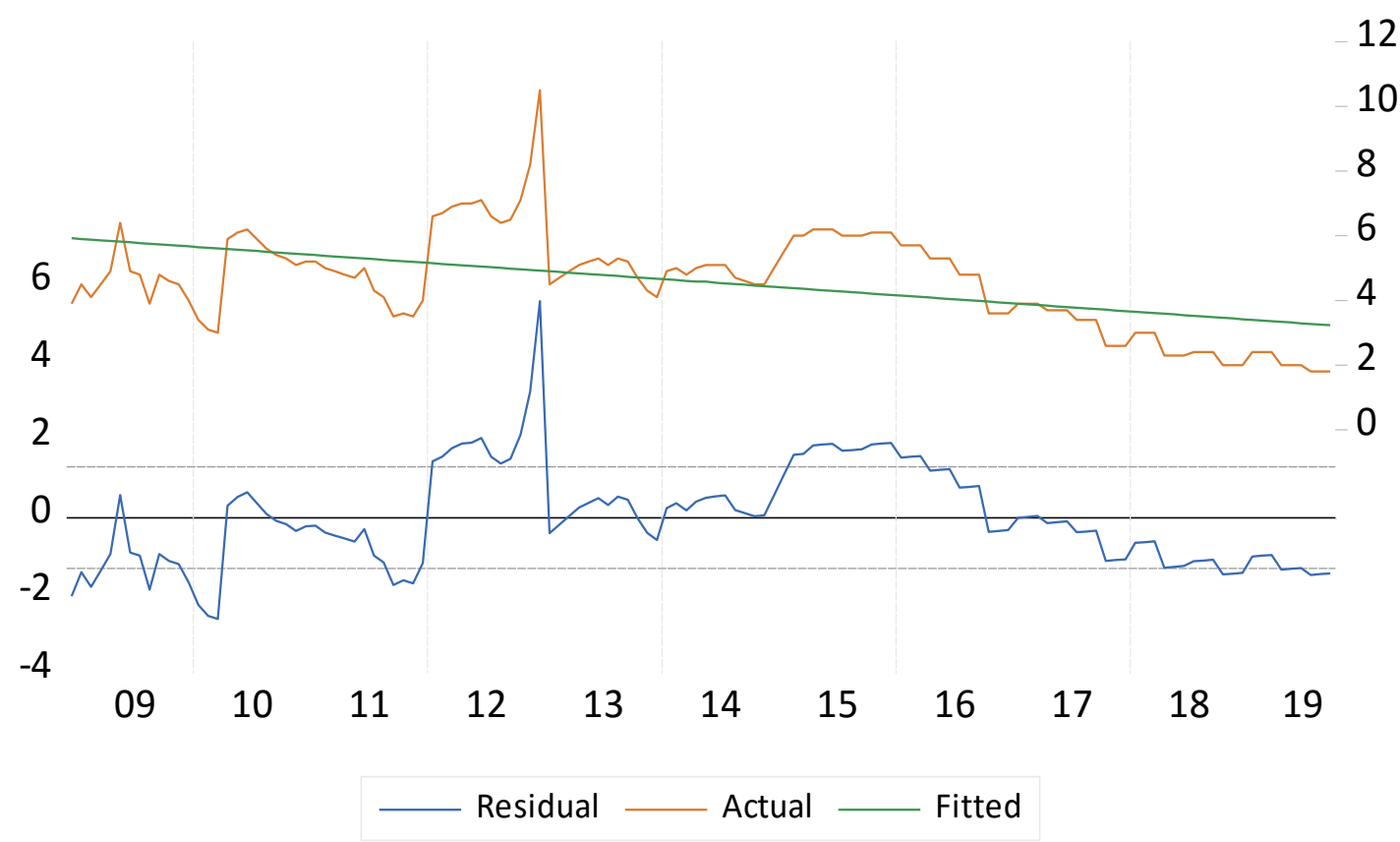

Figure2. U.S. Personal Saving Rate

Note: The Regression of the time trend of personal saving rate is:

$$
\begin{aligned}
& U S P S R=8.423^{\text {***** }}-0.021^{\text {***** }} t \\
& (0.574) \quad(0.003) \\
& R^{2}=0.267, \quad S E R=1.306, \quad F=46.674, \quad D-W=0.340, \quad N=130
\end{aligned}
$$

\footnotetext{
${ }^{73}$ See, "Fed Cuts Rates by a Quarter Point in Precautionary Move", Central bankers say move protects against risks posed by muted inflation, global growth concerns. https://www.wsj.com/articles/fed-cuts-rates-by-aquarter-point-ends-portfolio-runoff-11564596200? $\mathrm{mod}=$ article_inline\&mod=article_inline\&mod=article_inline . See also, https://www.wsj.com/articles/powell-says-fed-prepared-to-provide-stimulus-if-a-slowdown-hits-u-seconomy-11566568965. Fed Chairman Jerome Powell's press conference on September 18, 2019 carried a subtle message for President Trump: If you are worried about an economic slowdown, find a way to cool down the trade war. See, "Analysis: Powell's Subtle Messaging to Trump on Trade Fight". The globalist Fed chairman mentioned trade 20 times at his news conference on Wednesday (9/18/2019). https://www.wsj.com/articles/ analysis-powells-subtle-messaging-to-trump-on-trade-fight-11568971800 . On January 15, 2020, the U.S. and China signed a Trade Agreement. See, The Wall Street Journal, January 16, 2020, pp. A1, A7, B1, and B12.

74 Thus, from $\bar{i}_{F F}=1.50 \%-1.75 \%$ to $\bar{i}_{F F}=0.00 \%-0.25 \%$. See,

https://www.federalreserve.gov/newsevents/pressreleases/monetary20200129a1.htm

${ }^{75}$ TV News ANTENNA, 8/1/2019. See also, "Brexit: Day arrives for the UK to finally leave the EU after 47 years", https://www.9news.com.au/world/brexit-news-day-finally-arrives-uk-leaves-eu-live-updatesblog/57b16099-f01b-4b61-b6e7-fdb076d07671. This is actually a success (a win) of democracy!.. See, https://www.bing.com/search?q=wsj+brexit+arrives $\% 2 c+a+$ watershed+moment+for+britain+and+the+eu\&FOR $\mathrm{M}=\mathrm{AWRE}$. See also, "Support for Brexit is collapsing as poll finds big majority of British people want to be in the EU”, https://www.businessinsider.com/brexit-poll-most-british-people-want-to-rejoin-eu-2020-6
} 
the oppressive EU. ${ }^{76}$ The best solution for the society will be to make all these central banks public; so they will work only for the people, for their nations, and for their wellbeing and not ignoring them, but these banks control (influence) our investments and economic decisions, our destiny, and our economic welfare. ${ }^{77}$ and do not respect the will of the citizens? U.K. had a referendum and they voted in favor of leaving



Figure3. U.S. Personal Saving Rate and Growth of U.S. Personal Consumption Expenditures

Federal Reserve officials signaled plans to keep interest rates near zero for years and said they were studying how to provide more support to a U.S. economy battered by the coronavirus and related shutdowns. "We are strongly committed to using our tools to do whatever we can and for as long as it takes to provide some relief and stability," Fed Chairman Jerome Powell said Wednesday (6/10/2020) at a virtual news conference after a two-day policy meeting. ${ }^{78}$ Thus, the unethical bail in and bail out will continue for some more years, due to this latest healthcare, financial, economic, and the worst of all, the November 3, 2020 election crisis and its results.

\subsection{Fiscal Policy and Ethics}

Undoubtedly, except a good monetary policy, the country needs a good fiscal policy and a fair trade policy. Countries must be independent, homogeneous, ${ }^{79}$ self-sufficient, and sovereign

\footnotetext{
${ }^{76}$ This was the United Kingdom European Union membership referendum; also known as the EU referendum, the European referendum and the Brexit referendum, which took place on June 23, 2016 in the UK and Gibraltar to ask the electorate if the country should remain a member of, or leave the EU, under the provisions of the European Union Referendum Act 2015 and also the Political Parties, Elections and Referendums Act 2000. The referendum resulted in $51.9 \%$ of votes being in favor of leaving the EU (17,410,742 votes). The government of that time had promised to implement the result, but the country is still in the union for over 4 more years, until December 31, 2020. Greece had also a referendum on July 5, 2015 and 61.31\% vote NO to EU memoranda, but EU made it YES. Greece has to leave the Euro-zone, otherwise the country has no future. https://en.wikipedia.org/wiki/2015_Greek_bailout_referendum . This liberal EU is actually a controlled trap and not a union. See, Kallianiotis (2018).

${ }^{77}$ Unfortunately, lately, globalists' and ecumenists' "religion" is the Ecology (global warming); but last year's winter disappointed them with temperatures $-50 \% \mathrm{~F}$ and heavy snow storms all over the north hemisphere. The rest of our "objectives" are all under their control even before the French Revolution (1789). See, Kallianiotis (2017b). Also see, https://www.jacobinmag.com/2015/07/french-revolution-bastille-day-guide-jacobins-terror-bonaparte/.

${ }^{78}$ See, Fed Officials Project No Rate Increases Through 2022. https://www.wsj.com/articles/fed-debates-howto-set-policy-for-the-post-pandemic-economy-11591781402

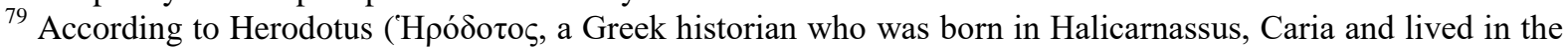
fifth century B.C., c. 484-425 B.C. and referred as "The Father of History"), he was saying that a nation must

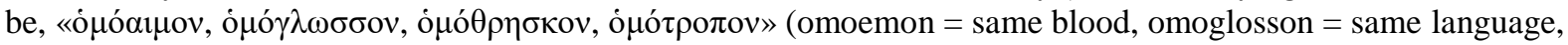
omothriskon $=$ same religion, omotropon $=$ same ways, behaviour. Today, the dark powers try to destroy
} 


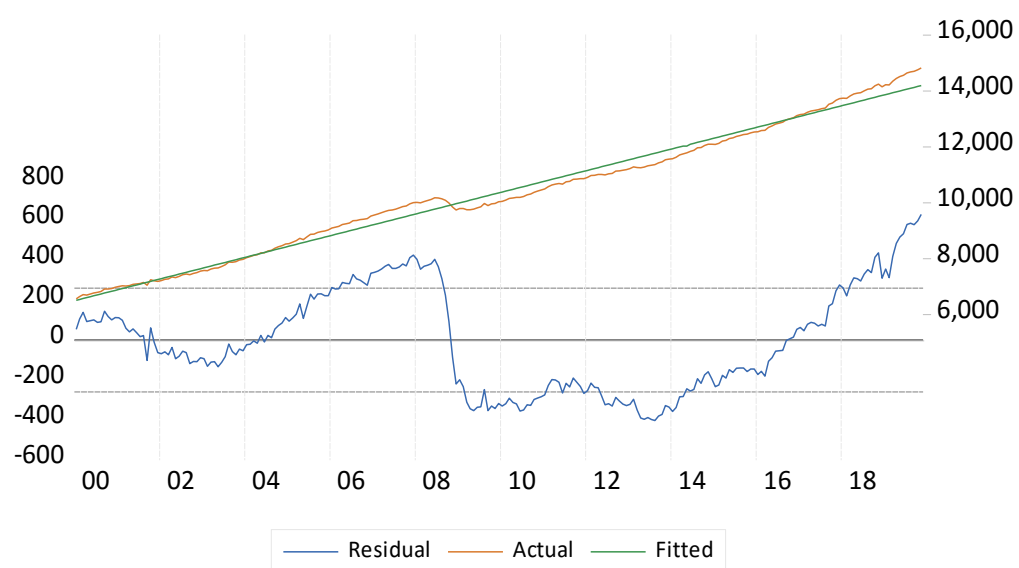

Figure4. U.S. Personal Consumption Expenditure and its L-T Trend

Note: The Regression for the personal consumption time trend is:

$$
\text { USPCE }=6,091.631^{* * * *}+32.282^{* * * *} t
$$

$$
R^{2}=0.987, \quad S E R=260.049, \quad F=17,529.91, \quad D-W=0.023, \quad N=239
$$

nations, too. The unfair free trade policies have destroyed the U.S. and the EU economies. ${ }^{80}$ Also, social welfare is necessary to improve the wellbeing of the citizens of a country, but the distribution of the country's wealth plays a major role towards this objective. Consumption is affected positively by income, prices, and loans; it is affected negatively by unemployment, outsourcing, wealth deprivation, low interest rate (rate of return on investment), taxes, and risk. An increase in wealth does not always increase consumption because this wealth belongs to the rich people and already they consume at their maximum level; then, the distribution of wealth is the problem (Graph 6) ${ }^{81}$ The

sovereign nations by ruining their homogeneity (with the illegal immigrants) and by changing their traditions and cultures and they are "very successful" (sic), due to our ignorance of history by their pseudo-politicians.

${ }^{80}$ See, Kallianiotis (2018).

${ }^{81}$ Wealth inequality in the United States, https://en.wikipedia.org/wiki/Wealth_inequality_in_the_United_States

Graph 6: Shares of Wealth in the U.S.

\section{The wealthiest Americans own an increasing share of wealth}

Shares of wealth in the United States by wealth percentiles, 1989-2016

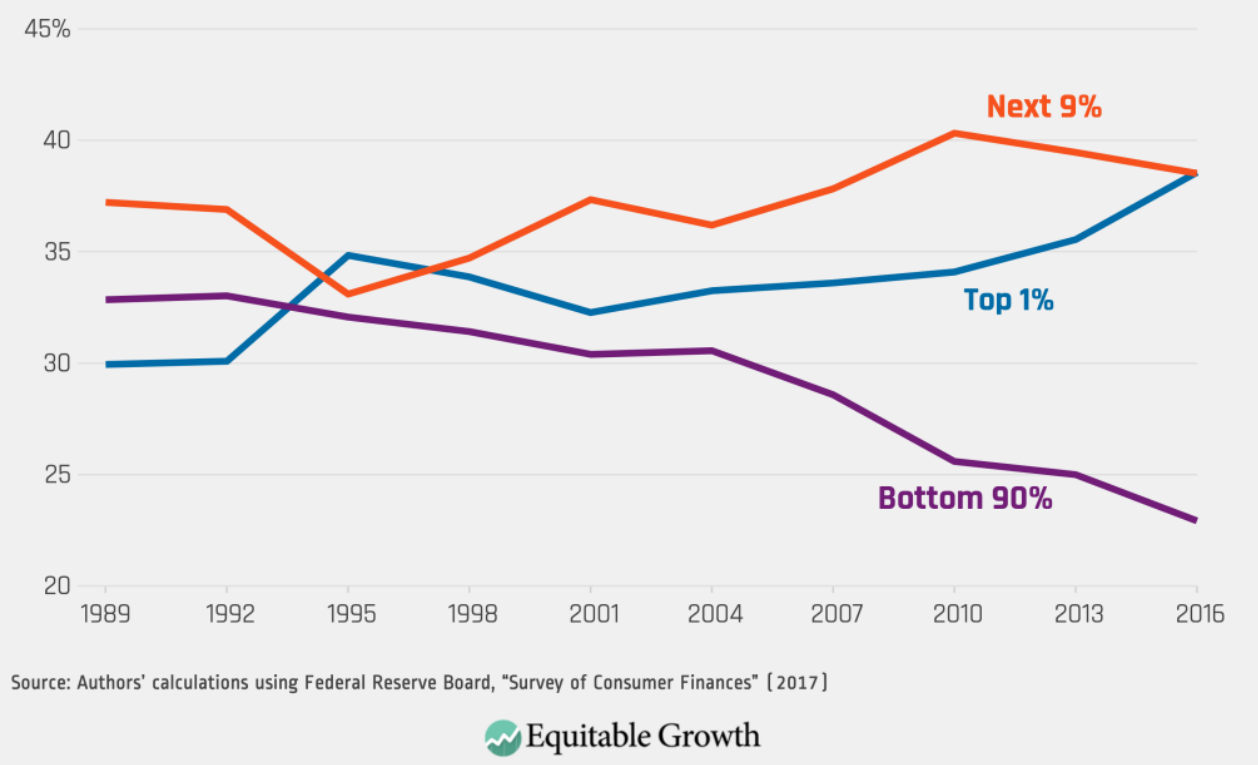


wealth of the poor people (bottom 90\%) is falling and for this reason consumption (Graph 7) is falling, ${ }^{82}$ too. Prices are going up and consumption is increasing (inelastic demand for consumer's goods and services), Figure 4.

Taxes and government spending are tools of fiscal policy. These two instruments have to be used with a fair, effective, and optimal way that means ethically. Unfortunately, there is an unfair and unethical tax, the property tax, which is imposed on individuals home. This home does not generate any income, it has only expenses and the family has to pay "rent" (property taxes) for its own home. Thus, both extreme systems are against private property; the poor individual has no property because he cannot afford to pay property taxes. Property taxes have to be abolished for homes that they house the family of the owner. Only progressive income taxes are sufficient for a democratic and prosperous nation.

In enacting fiscal policy, which encompasses the budgeting process of a sovereign government as well as the justifications for budget decisions, politicians make historical compromises with, and commitments to, their ethical ideals in the form of real initiatives and operations of government because there is an enormous conflict of interest, an existing establishment, a strong lobby, and a deep swamp ( $\pi \alpha \rho \alpha \kappa \rho \alpha ́ \tau o \zeta)$. Unlike proclamations of ethical probity and the censures of their competitors that politicians may utter during their campaigns and during their speeches, but in office they cannot satisfy their promises. Due to oppositions from the different branches (legislative, ${ }^{83}$ executive, and judicial) and their different political parties (Republicans and Democrats) of government, the budgetary and fiscal decisions made by lawmakers even though that they are key components of their effective morality, a morality that has, by design, enormous and differential impact on others (citizens and businesses) cannot be materialized. Unfortunately, it depends on the will of the opposition party and especially if this party has the majority of the senate, nothing can pass because they want to show to the voters that this administration has failed and they must vote for the other party that is more

Source: https://equitablegrowth.org/the-distribution-of-wealth-in-the-united-states-and-implications-for-a-networth-tax/

See also, https://www.stlouisfed.org/open-vault/2019/august/wealth-inequality-in-america-facts-figures

Further see, https://www.brookings.edu/blog/up-front/2019/06/25/six-facts-about-wealth-in-the-united-states/

${ }^{82}$ Graph 7: Real Personal Consumption Expenditures (Percent Change from Preceding Period)

Also, Real Personal Consumption Expenditures (DPCERO1Q156NBEA) (Percent Change from Quarter One Year)

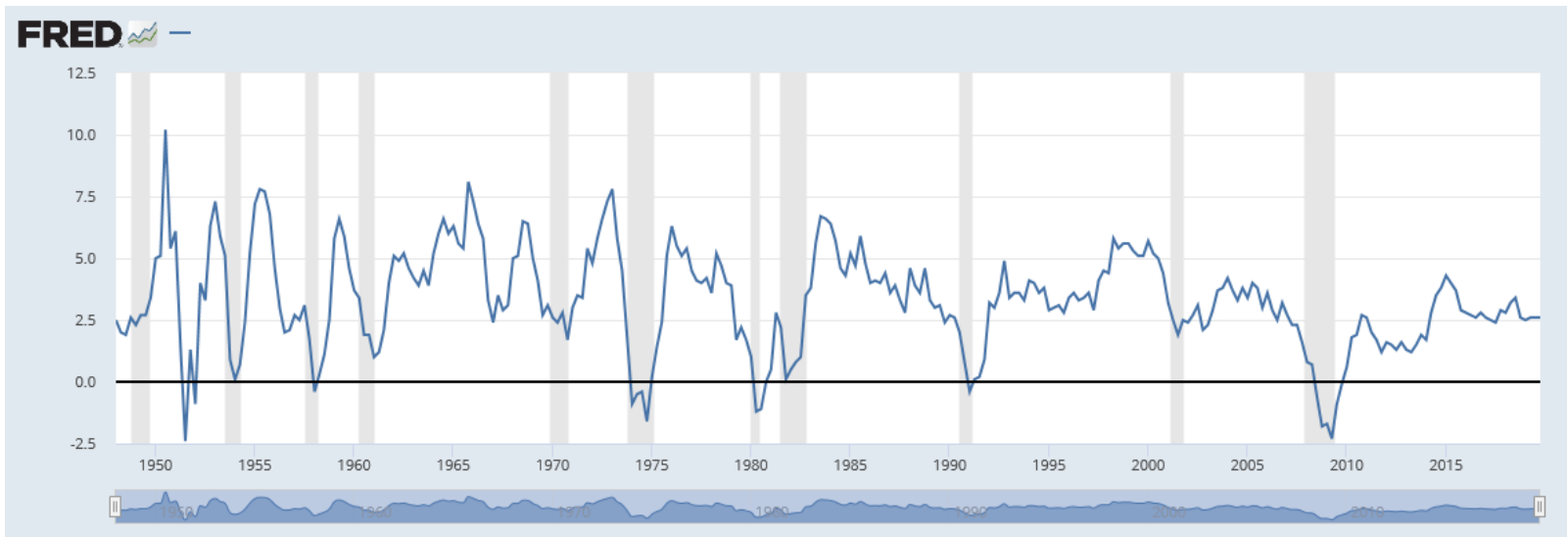

Source: https://fred.stlouisfed.org/series/DPCERO1Q156NBEA

${ }^{83}$ The legislative branch, the Congress is composed of two parts:

(1) Senate: There are two elected Senators per state, totaling 100 Senators. A Senate term is six years and there is no limit to the number of terms an individual can serve.

(2) House of Representatives-There are 435 elected Representatives, which are divided among the 50 states in proportion to their total population. There are additional non-voting delegates, who represent the District of Columbia and the territories. A Representative serves a two-year term, and there is no limit to the number of terms an individual can serve. 
effective. ${ }^{84}$ During the last year (2020), we saw that the federal system is not very effective, too. Governors and mayors, in different states and cities, do not follow administration's orders or directions. Judges also are cancelling or ban executive orders. (Sic).

Economists along with affiliated other benevolent social scientists would need to develop a set of ethical, moral, "minimum mandatory" and "best practices" analyses of the macro-economy that will maximize objectively the social welfare of the citizens. This would formalize the guidelines and the tools for controlling liquidity, efficiency, and effectiveness in the economy via a combined fiscal and monetary policy. Some of these analyses are already executed by various government agencies and the private central banks around the world, but are not in coordination and are formalized by economists into a set of decision support tools for policymakers. Economic variables and parameters of the economy that these tools would analyze include: ${ }^{85}$

(i) Appropriate Budgetary Accounting: The priorities of fiscal policy are tax revenue $(T)$, government expenditures $(G)$, budget deficits $(B D),{ }^{86}$ national debt $(N D),{ }^{87}$ and financing of national debts. ${ }^{88}$ Sustainability of national debt ${ }^{89}$ is a very important ethical issue or the country's wealth is confiscated by the foreign creditors (hedge funds, etc.). Nomenclature

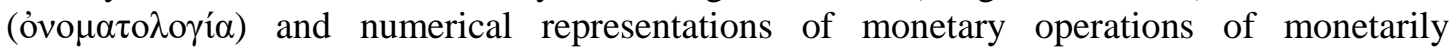
sovereign governments are necessary (have common similarities and differences with business and household accounting; e.g. can "deficits" within national currency exist? Is a balance sheet the correct accounting format?).

(ii) Unemployment: The fiscal policy objective is full employment or unemployment at the natural level $\left(u^{N}\right)$. People must have full time jobs and a dissent income that can satisfy their needs. ${ }^{90}$ Unemployment insurance is necessary for a person who lost his job, but this payment cannot exceed the minimum wage because he will never become interested to find a job.

(iii) Inflation: This is an objective of public policy, but mostly of monetary policy and less of a fiscal one. ${ }^{91}$ If an individual has a dissent income, he can pay even a little higher price, but if he is unemployed, zero inflation is also bad for him. Thus, employment must be the number one objective of fiscal policy. This to happen, we need to bring manufacturing back home. An economy cannot depend only on services (tertiary sector). The country has to become competitive again, as it was in 1960s and 1970s. The latest trend will destroy the country. ${ }^{92}$

\footnotetext{
${ }^{84}$ I remember very well my professor of Microeconomics in my Graduate School, where he was saying that "the politicians have only one objective, to be reelected and nothing else". Now, after forty years, I see that he was absolutely right. The "professional" politicians have no other objective. What a misfortune for our societies, today!..

${ }^{85}$ See, Hoexter (2013b).

${ }^{86}$ The federal budget deficit was about \$3.1 trillion in fiscal year 2020 (15.2\% of GDP). https://www.cbo.gov/topics/budget

${ }^{87}$ The U.S. national debt was \$27.411 trillion with December 8, 2020. https://www.usdebtclock.org/

${ }^{88}$ See, Federal Debt. https://www.gao.gov/americas_fiscal_future?t=federal_debt . See also, HOW DOES THE TREASURY ISSUE DEBT? HTTPS://WWW.PGPF.ORG/BLOG/2020/04/HOW-DOES-THE-TREASURYISSUE-DEBT

${ }^{89}$ See, Kallianiotis (2017a, p. 51).

${ }^{90}$ An elementary school teacher was asking her students, "what will you become when you grow up?" and a student said, "I will like to be on welfare". The official unemployment rate with May 2020 was $13.3 \%$. See, THE EMPLOYMENT SITUATION -MAY 2020.

file:///C:/Users/JK/AppData/Local/Microsoft/Windows/Temporary\%20Internet\%20Files/Content.IE5/U5CSIO WY/empsit.pdf . The official unemployment rate was in February 2020: 3.5\%, March: 4.4\%; Then came the coronavirus lockdown and it increased in April to 14.7\%, in May fell to 13.3\%, and in November to $6.7 \%$. https://radingeconomics.com/united-states/unemployment-rate . The economy needs a trade-off (balance) between heath care and economic health. The May 2020 ShadowStats Alternate Unemployment was 34.0\%, $36.5 \%$ net of BLS errors, and in November became $26.3 \%$. See,

http://www.shadowstats.com/alternate_data/unemployment-charts

${ }^{91}$ It was $0.1 \%$ in May 2020, due to the recession and in October 2020, it was $1.2 \%$.. See, https://tradingeconomics.com/united-states/inflation-cpi . The SGS give an inflation of 7\% and $8 \%$ for the same period.

92 The U.S. faces an enormous threat from China (economic, technological, and military); but, the media and the controlled "establishment" lie by saying that the treat is Russia.
} 
(iv) Balance of Trade: The fiscal policy must equalizes exports and imports $(T A=X-M=0)$. A deficit in trade account means import of unemployment from the foreign countries. The outsourcing of our manufacturing and the imports of good from abroad have made the country dependent on foreign production and contextual ( $\dot{\varepsilon} \xi \eta \rho \tau \eta \mu \varepsilon ́ v \eta)$ to other nations. We saw, lately, with the Wuhan coronavirus, our dependence on Chinese pharmaceuticals. This policy is unethical because it is of high risk and anti-American. ${ }^{93}$

(v) Sovereign Debt Issuance and Management: Sovereign debt is a central government's debt. ${ }^{94}$ It is debt issued by the national government in a foreign currency in order to finance the issuing country's growth and development. The stability of the issuing government can be provided by the country's sovereign credit ratings, ${ }^{95}$ which help investors weigh risks when assessing sovereign debt investments.

(vi) GDP and Alternatives to GDP (Net Economic Welfare, NEW): Because GDP does NOT measure the following factors. 1. Health and well-being, 2. Infant mortality, 3. Morbidity, 4. Suicide rates, 5. Crime, 6. Poverty, 7. Environmental health/natural environment/God's creation, 8. Infrastructure such as highways and bridges, 9. Family breakdown, 10. Divorces,

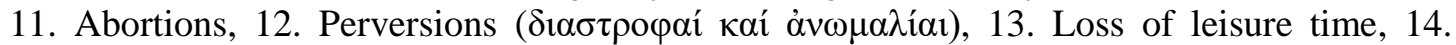
Desertion of arts or desecration of arts (statues) ${ }^{96} 15$. Cost of commuting to work, 16. Lack of civility in communities, 17. Riots, 18. Lack of concern for future generations, 18. Income gap, 19. Herd mentality, 20. Lack of historical perspective, 21. Education, 22. Tradition/culture, 23. Value system and many others. ${ }^{97}$ Thus, the current GDP measurement is overvalued. An alternative, like the Net Economic Welfare (NEW) can be a more accurate one.

(vii) Material Sustainability (Water, Waste, Food Production): ${ }^{98}$ Natural resources, water, energy, minerals, ores, land, agricultural products, etc. are necessary to make the country independent and self-sufficient. The primary sector of the economy is the most important one.

(viii)Public goods: These are part of the public wealth and belong to the current and future generations. The government has to take precedence over private interests, contradicting the

\footnotetext{
${ }^{93}$ The outbreak of the new coronavirus has forced a large number of Chinese drug manufacturers to shut down. That could be bad news for the United States, which depends on China and India for its drug supply. See, https://www.cfr.org/in-brief/coronavirus-disrupt-us-drug-supply-shortages-fda . Also see, "Why You Shouldn't Trust Anyone Who Claims 80 Percent of America's Drugs Come From China", https://reason.com/2020/04/06/why-you-shouldnt-trust-anyone-who-claims-80-percent-of-americas-drugscome-from-china/

94 "OECD Sovereign Borrowing Outlook 2019, Sovereign Borrowing Outlook for OECD Countries", file:///C:/Users/JK/AppData/Local/Microsoft/Windows/Temporary\%20Internet\%20Files/Content.IE5/U5CSIO WY/Sovereign-Borrowing-Outlook-in-OECD-Countries-2019.pdf . See also, UN/DESA Policy Brief \#72: COVID-19 and sovereign debt, https://www.un.org/development/desa/dpad/publication/un-desa-policy-brief72-covid-19-and-sovereign-debt/

${ }^{95}$ We saw the problems with these ratings during the Euro-zone debt crisis; subjectivity, unfairness, and depravity. See, Kallianiotis (2018).

96 This behavior is going on in the U.S. the last months with this anti-American Cultural Revolution. See, "Welcome to America's Cultural Revolution", https://www.nationalreview.com/2020/06/welcome-to-americascultural-revolution/. See also, "Tucker Carlson: Cultural Revolution has come to America - brainwashing underway", https://www.foxnews.com/opinion/cults-allies-george-floyd-tucker-carlson ${ }^{97}$ See,

file:///C:/Users/JK/AppData/Local/Microsoft/Windows/Temporary\%20Internet\%20Files/Content.IE5/51F9Y8A K/GDP_and_GPI.pdf

${ }^{98}$ In the United States alone, 40 percent of food gets tossed every year — and that amounts to \$162 billion in waste annually, according to the Natural Resources Defense Council. This can serve 58,064,516,129 meals using the national average amount spent on a meal, $\$ 2.79$.

https://www.rescuingleftovercuisine.org/challenge?gclid=Cj0KCQjw0Mb3BRCaARIsAPSNGpU1E3sc0UIRHs 3mF1jv1WLnI_zIsAOTrfffPEUK2mQcirM7xky5CeAaAu01EALw_wcB. Also, FOOD SYSTEMS \& SUSTAINABLE AGRICULTURE: Food Tech, from Farm to Table, https://www.theimpactivate.com/foodtech-from-farm-totable/?gclid=Cj0KCQjw0Mb3BRCaARIsAPSNGpVBBxWIPmD02UvHs7kcntcbsgpC_DxFIF3r12gDk1OJ2UPKD4xp3UaAvokEALw_wcB . Further, Sustainability and Materials, file:///C:/Users/JK/AppData/Local/Microsoft/Windows/Temporary\%20Internet\%20Files/Content.IE5/51F9Y8A K/pga_062612.pdf
} 
propaganda, which suggests that private interests are infallible and they are working for our social interest, too. From this stems the legitimacy of government to enforce laws and institute regulation of private interests for the common good (all the citizens). The public goods exist to support and improve the private goods, without depriving individuals of their freedoms and rights.

(ix) The Endless wars: The country is involved in wars for so many years with enormous cost and zero benefits. ${ }^{99}$ Actually negative benefits for the U.S. because the rest of the world consider us as "the most dangerous nation for the global peace".

(x) Relentless attack on the government, the President, and the administration: ${ }^{100}$ The opposition party (Democrats) do not want to accept that they lost the 2016 elections and by working for four years to find ways to dethrone the legitimate President, they designed the mail-in ballots, which led to voter fraud of 2020 and "won" the elections. (Sic).

(xi) Ethical commitment to the domestic value system: The integrity, the continuance, and the improvement of the nation and its values (independence, self-sufficiency, autarky, respect of nations' sovereignty, culture, civilization, democracy, election integrity, value system, etc.) are necessary public policies.

(xii) Ethical commitment to the future of the nation and to the future generations: The future of a nation depends on its new generations (inheritance), which need to obtain everything that they need for their lives (health, education, values, culture, history, democracy, constitution, law and order, personal freedoms, liberty, etc.). There must be improvements from one generation to the other. $^{101}$

\footnotetext{
${ }^{99}$ There is no need for endless wars since 1940. These interferences have no benefits for the Americans, only cost (in humans and money), hatred, and hostility. President Trump so far has avoided all these wars and has to face the opposition from the warlike generals (and John Bolton and others). At least 800,000 people have been killed by direct war violence in Iraq, Afghanistan, Syria, Yemen, and Pakistan. More than 310,000 civilians have been killed in the fighting. An additional 12.6 million Syrians are displaced, many as a result of the U.S. war against the Islamic State in Syria. These people are now, as immigrants to Europe (mostly in Greece, more than 3 millions, $30 \%$ of the population of this small country). See, https://watson.brown.edu/ costsofwar/costs/human. Through Fiscal Year 2020, the United States federal government has spent or obligated \$6.4 trillion dollars on the absurd wars in Afghanistan, Pakistan, and Iraq. https://watson.brown.edu/
} costsofwar/costs/economic . See also, Immigration to Greece,

https://en.wikipedia.org/wiki/Immigration_to_Greece .

${ }^{100}$ This behavior by the opposition party (Democrats), the liberals, the globalists, and many others is unique in the U.S. political history. It shows lack of respect to our institutions and to our democracy. They started with the impeachment of Donald Trump, which was initiated on December 18, 2019, on charges of abuse of power and obstruction of Congress. Trump was later acquitted by the Senate on these two counts of impeachment on February 5, 2020. The Democrats alleged that he had solicited foreign interference (Russia) in the 2016 U.S. presidential election (because they lost the elections). The inquiry reported that Trump withheld military aid and an invitation to the White House to Ukrainian president Volodymyr Zelensky in order to announce an investigation into Joe Biden. After the impeachment, they found the coronavirus and the lockdowns to blame the President; then, its negative effects on the economy, and now, by encouraging the liberal riots to destroy and loot stores and monuments. Even we have the creation, with the tolerance of the liberal local leaders (mayor and governor), of an "autonomous zone" in Seattle. The worst of all was the election irregularities (voter fraud) on November 3, 2020. Now, the country has a new president and the rest of the world is ready to take advantage of our multiform crises. (Sic). See, https://en.wikipedia.org/wiki/Impeachment_of_Donald_Trump. See also, The State of Capitol Hill Autonomous Zone (CHAZ), https://www.city-journal.org/seattle-chaz?gclid=Cj0KCQj w0Mb3BRCaARIsAPSNGpVH93fp-gXGEn09Y5tUNYDVmN9-

BhpaLKdN8Cle4eeYkj_dzFsjhj8aAhkqEALw_wcB. See also, "Seattle's 'Autonomous Zone' is latest escalation in city's lurch to the left: What to know", https://www.foxnews.com/politics/seattle-history-liberal . Further, Nascar banned Confederate flags from races. Meanwhile, President Trump said he will "not even consider" renaming military bases that bear the names of Confederate generals, even though top Pentagon officials said they're open to a discussion. Trump opposes efforts to remove Confederate commanders' names from military bases, https://www.cnn.com/2020/06/10/politics/donald-trump-army-bases-renaming/index.html . In addition, The Hill's Campaign Report: Republicans go on attack over calls to 'defund the police', https://thehill.com/homenews/campaign/501709-the-hills-campaign-report-calls-to-defund-police-enter-2020campaign.

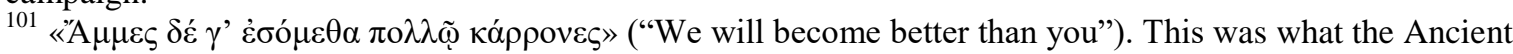
Spartan children were telling to their parents and grandparents. http://mariasot.blogspot.com/2016/02/blogpost_16.html 
All these issues are ethical and reveal the social and political state of a nation. United States as an advance nation has to improve its wellbeing through democratic improvements. Unfortunately, at the moment, there is only a hazy light at the horizon.

\section{ETHics In FinANCIAL AND Political InSTITUTIONS}

Financial institutions must act with fairness and in good faith to attract clients and contribute to the society for the benefits they receive. ${ }^{102}$ An untrustworthy bank, stockbroker, insurance company or any other financial institution will lose its clients and will go bankrupt. There is the doctrine of utmost good faith ${ }^{103}$ which is a minimum standard, legally obliging all parties entering a contract to act honestly and not mislead or withhold critical information from one another. The doctrine of utmost good faith applies to many everyday financial transactions and is one of the most fundamental doctrines in insurance law. ${ }^{104}$

Investors trust financial institutions, especially banks (because they are FDIC insured), with their money and expect them to invest it with integrity and pay them a dissent return (i.e., a positive real deposit rate). Unfortunately, banks are "paying" a negative real deposit rate $\left(r_{D}=i_{D}-\pi<0\right)$ since 2008. This is unfair and unethical for the poor risk-averse depositors. The responsibility of these negative returns falls on another institution, the private central bank (the Fed). All market risks considered and based on these risks, investors expect the highest return and put their faith in the hands of these professionals that they consider them ethical and experts for the job they provide. Investors' confidence is necessary for the success of the financial institutions and the entire financial industry. The CFA Institute provides Code of Ethics and Standards of Professional Conduct that must be used by professionals. ${ }^{105}$ They outline best practices, integrity, duties to clients and employers, investment analysis, recommendations, conflicts of interest, and responsibilities of professionals and of the financial institutions.

Ethical issues can be created from: (1) Self-interest, which can be developed into greed ( $\dot{\alpha} \pi \lambda \eta \sigma \tau i \alpha)$, selfishness $\left(\dot{\varepsilon} \gamma \omega 1 \sigma \mu{ }^{\prime} \varsigma\right),{ }^{106}$ fear, corruption, exploitation, etc. and is growing at the expense of the other investors. Greediness can become a very serious psychological sickness. ${ }^{107}$ (2) Stunted moral development, that is the process through which children develop proper attitudes and behaviors toward other people in society, based on social and cultural norms, religion, value system, rules, laws, ${ }^{108}$ parents knowledge ${ }^{109}$ teachers, ${ }^{110}$ and the knowledge of Truth. ${ }^{111}$ (3) Legal imposition, which

\footnotetext{
${ }^{102}$ See, Kallianiotis (2002).

${ }^{103}$ Also known by its Latin name uberrimae fidei, https://www.investopedia.com/terms/u/uberrimae-fideicontract.asp

${ }^{104}$ Insurance is a contract, represented by a policy, in which an individual or entity receives financial protection or reimbursement against losses from an insurance company. The company pools clients' risks to make payments more affordable for the insured. Insurance policies are used to hedge against the risk of financial losses that may result from damage to the insured or his property, or from liability for damage or injury caused to a third party.

${ }^{105}$ See, Code of Ethics and Standards of Professional Conduct, https://www.cfainstitute.org/ethicsstandards/ethics/code-of-ethics-standards-of-conduct-guidance

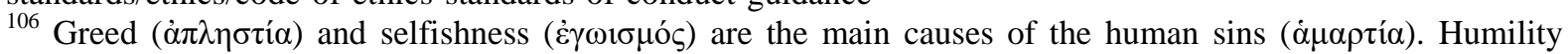

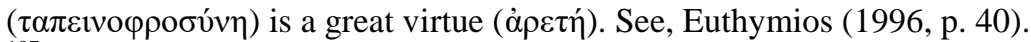

${ }^{107}$ But, the Bible, "Command those who are rich in this present world not to be arrogant nor to put their hope in wealth, which is so uncertain, but to put their hope in God, who richly provides us with everything for our enjoyment. Command them to do good, to be rich in good deeds, and to be generous and willing to share. In this way they will lay up treasure for themselves as a firm foundation for the coming age, so that they may take hold of the life that is truly life." (1Timothy 6:17-19). See, https://www.biblestudytools.com/topical-verses/bibleverses-about-greed/

${ }^{108}$ Unfortunately, lately, we cannot trust laws because many of them are unethical, unfair, perverse, atheistic, and even against human life (i.e., abortion, euthanasia, etc.).

${ }^{109}$ Parents are usually very young and unexperienced when they have their children and it is difficult to give correct advices to their children. The traditional families had also the grand-parents, who help with their experience the grand-children. Today, they have been thrown to nursing homes and are dying from COVID-19; $81 \%$ of coronavirus deaths are in nursing homes. (ABC News, 6/13/2020). These acts are not unethical, but criminal.
} 
is different than moral behavior because human laws are generally incomplete rules created for specific period and by specific people (the party in power, its ideology, the lobbyists, and other pressures). Thus, someone can be and behave legally according to Cesar, but can be morally wrong and against God's law. ${ }^{112}$ (4) Professional duty in conflict with company's policy, when a reward system can induce unethical behavior. For example, a loan manager of a bank offers mortgages without the $20 \%$ down payment, just to receive the bonus of offering too many loans and his behavior is increasing the risk of the bank. (5) Individual responsibility is neglected to satisfy the demands of clients, event acting unethically to please a good looking customer ${ }^{113}$ or anything else.

Political institutions in democratic societies are responsible for keeping the constitution, the laws and order, security and safety, fair elections, ${ }^{114}$ life, liberty, and the pursuit of happiness for the citizens and to protect their constitutional rights. Political ethics (or political morality or public ethics) is the practice of making moral judgements about political action and political agents. ${ }^{115}$ It covers two areas. The first is the ethics of process (or the ethics of office), which deals with public officials and the methods they use. ${ }^{116}$ The second area is the ethics of policy (or ethics and public policy), ${ }^{117}$ which concerns judgments about policies and laws. ${ }^{118}$ Political ethics not only permits leaders to do things that would be wrong in private life, but requires them to meet higher standards than would be necessary in private life. For example, they may have less of a right of privacy than do ordinary citizens, and no right to use their office for personal profit. The major issues, here, ultimately concern the concept of conflict of interest. ${ }^{19}$

The concept political morality can be easily understood when knowing what the roots of the term are and the gradual development. The values and expectations of political morality are derived from the principles of justice. Political conception of justice is ultimately based on not only the values those are expected to follow, but most importantly, the common good of an individual. ${ }^{120}$ In large political institutions and government it is often not possible to tell who is actually responsible for the outcomes - a problem known as the problem of many hands. ${ }^{121}$ Corruption and abuse of power is another problem of financial and political institutions. These are common in the political establishment (the swamp), today.

Personal or private morality and political morality are often viewed as a conflict of interest. However, it is important to know that these two concepts of morality can also maintain a common positive relationship between themselves. Whether an individual is involved in the political domain as an authority or as an active civic participant, these values bleed through to the personal sector of morality

\footnotetext{
${ }^{110}$ Teachers, today, are professional with very diverse background and value system and mostly, they try to keep their jobs by obeying to laws and politically correct regulations, which many of them are unethical and bad for the children. Today, the teachers' unions do not want even to open the schools. ( Sic).

${ }^{111}$ The correct human behavior is coming from the ancient moral philosophers and the Revelation. The human laws are usually subjective and incomplete; some of them are also discriminatory and wrong, as we see with our crisis, lately in the U.S. See, "Feds comb Facebook to hunt down alleged rioters and looters",

https://www.politico.com/news/2020/06/12/facebook-riot-loot-justice-department-314567 . See also, http://www.healthofchildren.com/M/Moral-Development.html\#ixzz6Pph73Up8

${ }^{112}$ The legal system must have as its foundations God's Law, otherwise it is questionable. Because, "the beginning of the wisdom is the fear of God".

${ }^{113}$ Sexual harassment has become a major problem in our "civilized" world. See,

https://www.newamerica.org/better-life-lab/reports/sexual-harassment-severe-and-pervasive-problem/summary-

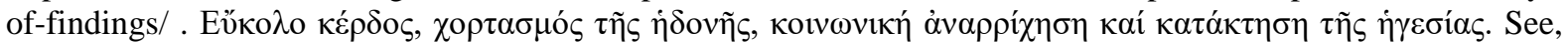
Euthymios (1996, p. 40).

${ }^{114}$ But in the 2020 U.S. elections, there were so many irregularities that question their integrity, as it happened in third world countries. See, "The Most Compelling Case for Overturning the Election". https://trumptrainnews.com/2020/12/02/the-most-compelling-case-for-overturning-theelection/

${ }^{115}$ See, Thompson (2012).

116 See, Hampshire (1978). and Thompson (1987).

${ }^{117}$ See, ethics . See also, public policy

${ }^{118}$ See, Gutmann and Thompson (2006). Also see, Bluhm and Heineman (2007) and Wolff (2011).

${ }^{119}$ See, Stark (2003).

${ }^{120}$ See, Leung (2016).

121 Thompson (2005).
} 
as well. An individual that learned the skills necessary in the political sector may apply these learned qualities in a setting outside of politics, often viewed as a private every day setting. In contrast, one that is entering the political setting may have already held the qualities and virtues that are expected in the professional setting. Therefore, the values and skills already held will then be applied to the new political setting, as anticipated. Reciprocity ( $\dot{\alpha} \mu \mathrm{o} \beta \alpha \iota$ ó $\tau \eta \tau \alpha)$, as in the context of deriving those traits are commonly present when entering the field, if the qualities were not already learned. Both concepts of morality include different expectations, but to say the least, there is a high correlation present between the two. Whether the virtues and values were acquired or previously held, they simply factor in and apply to both settings. Those that have emerged into the intense political sphere, knowing that virtues and morals can certainly be an influence, but building one's character can be substantially beneficial prior to the entrance. ${ }^{122}$ A person must learn morality since he is born from his parents, otherwise, his mistakes will be destructive for himself and the society.

Personal morality that depends on Christian faith, family values, true knowledge, and objective in life, is also factored into public morality. However, given the Liberal democracy ("progressiveness") present even in the United States, lately, public morality is often referred to as "formal" (conservative behavior). Abiding by the order of law, in addition, maintaining respect are simply two critical factors in order to achieve the concept of public morality. These elements are expected when an individual is actively participating in the political sphere, and ultimately required for the behavior of political authorities. ${ }^{123}$ Each citizen has his own belief and morals, in our heterogeneous society, toward a particular philosophy or a controversial topic, nonetheless it is the political authorities' duty to respect others' belief and advocate for their constituents beliefs while following the law and constitution for freedom of speech and different political view. ${ }^{124}$

In the other area of political ethics, the key issues are not the conflict between means and ends, but the conflicts among the ends themselves. For example, in the question of global interest, the conflict is between the claims of the sovereign nation and its citizens on one side and the claims of all "citizens of the world". ${ }^{25}$ In this case, priority must be given to the claims of nations, the welfare of the nation for which these politicians have been elected. In recent years some controlled liberals, known as globalists, have pressed the claims of all citizens of the world and against the citizens of a country (globalists vs nationalists and patriots). This ideology will destroy the nation, its history, its values, and its civilization, which is completely unethical.

Political ethics deals not mainly with ideal justice, but also with realizing moral values in democratic societies where citizens (and philosophers) disagree about what ideal justice is. Unfortunately, in a pluralist society, how if at all can governments justify a policy of progressive taxation, affirmative action, ${ }^{126}$ the "right" to abortion (to slaughter your own children), ${ }^{127}$ universal healthcare, ${ }^{128}$ free education, open borders, and the like? But, the wrong (even criminal policies) must be rejected for the nation to have future. Political ethics is also concerned with moral problems raised by the need for political compromise, whistleblowing, civil disobedience, and criminal punishment. ${ }^{129}$ The truth is always the majority, even though that the wrong view, today, can occupy $90 \%$ of the people with the controlled media, misinformation, propaganda, and the wrong education.

Democracy, today, faces many challenges with all these conflicts of interest, corruption, lawlessness, anarchy, and civil unrest. Increasing political inequality, the decline of widespread political participation, voter fraud, ${ }^{130}$ media and big Tech dishonesty, the increasing power of non-majoritarian organizations and institutions on the domestic and global stages, the rise of global problems, the

122 See, Mendeluk (2018).

123 See, Deveaux (2002).

${ }^{124}$ See, Mendeluk (2018).

125 Beitz (1999).

${ }^{126}$ See, affirmative action, Today, we have reached adverse discrimination and many abuses of these original Executive Orders of 1961, 1965, and 1968.

${ }^{127}$ This is the worst crime in human history, it is a criminal law. It causes the death not only to the child, but to his mother, father, family, decedents, and to the nation.

${ }^{128}$ See, universal healthcare

${ }^{129}$ See, Political compromise, whistleblowing, civil disobedience (i.e., peaceful protests or nonviolent resistance).

130 "The November 2020 U.S. election is an assault in the core of democracy." (Lou Dobbs, Fox Business, November 30, 2020). 
growing need for moral, ethical, and objective specialized expertise in an increasingly complex public policy environment, and the existence of often radical forms of social, political, immoral and perverse minorities all combine to exert significant pressure on existing democratic regimes. They also problematize many of our core moral, ethical, and traditional assumptions and principles about democracy and its justification. The theoretical strength of democracy over other regimes is grounded in strong commitments to political equality and individual liberty, best realized and protected by the constitutions of democratic systems. Individuals enjoy an equal ability to influence the political agenda, either directly (voting power) or via representatives, and to have their concerns feed into wider processes of decision making and policy formation. Functioning democracies provide meaningful opportunities for citizens to communicate their concerns to decision makers and thereby effectively track the will of the people. In a democratic government, citizens are free in so far as they live as equals under institutions and laws, which are accountable to them and which they could change or reject them, if they so wished, due to their inefficiencies.

\section{Ethics and the latest Financial and Social Crises: A Historical Perspective}

I did not want to be involved with this topic; but, I did for historical purpose. We need to learn from our mistakes and we have done too many the last forty years. Starting in 1980, we see the government to relax regulations; then, the shadow banking innovated and created new financial products to increase their revenue, but increased the risk enormously in our financial institutions. Banks made an extraordinary profit, which was paid to their executives as bonuses. Then, the repeal of the GlassSteagall Act in 1999; consequently, came the financial crisis, due to deregulations and Fed's bubble, which burst and deteriorated the risky business of investment banks that was revealed by Europeans in August 2007. All these problems have been developed from lack of ethical behavior and from many other factors ("ignorance") that led the world to the first global financial crisis of the $21^{\text {st }}$ century because of globalization ${ }^{131}$ and the enormous unnecessary complexity and innovations. After December 16, 2008, the Fed reduced the federal funds rate to zero until December 15, 2015 and caused the biggest bubble historically in our financial market. The DJIA fell to 6,547.05 (March 9, 2009), due to the first crisis and then, with Fed's policy it reached 29,551.42 (February 12, 2020), a growth by $23,004.37$ points or $351.37 \%$ (32\% p.a.). In January 2020 came from China the Wuhan coronavirus, which caused the second crisis of the $21^{\text {st }}$ century; the DJIA fell to 18,591.93 (March 23, 2020), it lost $10,959.49$ points or $37.09 \%$. Fed came up with a new monetary policy abandoning reserve requirements and went back to zero federal funds rate. The DJIA reached a new high of 30,303.37 (12/17/2020). The effectiveness so far is questionable.

A paradox is that the Federal Reserve stands ready to respond to climate-change related weather disruptions to the economy and is working to ensure banks' resilience from unexpected shocks tied to a warming global environment, Fed Chairman Jerome Powell told Congress in an April 2019 letter. ${ }^{132}$

${ }^{131}$ Komlos (2019b, pp. 243-253) gives 31 factors that contributed to this global financial crisis: (1) Greenspan's Ideology, (2) The Financial Innovations, (3) The Rise of the Shadow Banking System, (4) The Neglect of Systemic Risk, (5) Groupthink rendered Greenspan's view politically correct, (6) The Dot-Com Bubble, (7) The lowering of Interest Rates, (8) Credit Rating Agencies, (9) Excessive Faith in Quantitative Finance, (10) Endemic Trade Deficits, (11) Easy Credit, (12) Banks Lowered Underwriting Standards, (13) Expansion of Subprime Lending, (14) Predatory Lending, (15) Bubble in House Prices, (16) The Illusion of Tranquility was Deceptive, (17) Deregulation, (18) High Debt Burden, (19) Financialization, (20) Herd Mentality, (21) Mispricing of Risk, (22) Out of control Leverage, (23) Globalization, (24) Moral Hazard, (25) Lack of Historical Perspective, (26) Hubris was ubiquitous, (27) Culture, (28) Inequality of Income, (29) Corporate Governance, (30) Revolving Door (executive in finance were appointed to government position), and (31) Media (fake news).

132 "Although addressing climate change is a responsibility that Congress has entrusted to other agencies, the Federal Reserve does use its authorities and tools to prepare financial institutions for severe weather events," Mr. Powell wrote in a letter to Sen. Brian Schatz (D-Hawaii), on April 18, 2019. "Over the short term, these events have the potential to inflict serious damage on the lives of individuals and families, devastate local economies (including financial institutions), and even temporarily affect national economic output and employment," Mr. Powell wrote. "As such, these events may affect economic conditions, which we take into account in our assessment of the outlook for the economy," the central bank leader said. Mr. Powell's letter came in response to a January 25, 2019 letter from Mr. Schatz in which, according to Mr. Powell, the senator urged the Fed to manage climate-change risks to the financial system and to prepare the banks it supervises for similar contingencies. (Sic). See,

https://www.wsj.com/articles/fed-readying-financial-system-for-climate-change-shocks-11557247667 
(Sic). The worst of all is that a former Fed official (ex-president of the N.Y. Fed), William Dudley, said, "central bank should act to thwart Trump's re-election". This statement from a Fed official is completely unethical and people cannot trust this kind of institutions. These liberals are reviling even themselves with any audacity and without any shame anymore. ${ }^{133}$ They do not believe in democracy and they abuse their power, like secret services. As it was mentioned above, lately, the Federal Reserve has moved into overdrive to try to keep the U.S. economy from suffering lasting damage from the coronavirus pandemic. It announced an emergency interest rate cut back to zero percent on March 3, 2020 and rolled out new efforts, including slashing rates to zero and re-launching large-scale asset purchases. ${ }^{134}$ The European Union and the Euro-zone are in big trouble again (especially, Italy and Spain with the deaths of people and the entire world in deep depression from the politicians' lockdowns, due to this Chinese virus and their abuse of power) and the ECB follows the Fed ${ }^{135}$ and it is going a little deeper with its negative overnight deposit rates $\left(i_{\text {OND }}=-0.50 \%\right.$ ) since September 18 , $2019 .^{136}$ Where is this controlled secular world going? They ("the elites") want to terrorize people and to show that they are in control and not the democratically elected politicians. President Trump tries with all his means, but there are obstacles everywhere, from "scientists", ${ }^{137}$ "experts", academics, liberals, Democrats, ${ }^{138}$ big Tech, ${ }^{139}$ and the corrupted establishment. ${ }^{140}$ At the end, we saw all these election irregularities, too. For historical purpose, we have to say the truth, so future generations be able to avoid the same inhumane mistakes.

\footnotetext{
${ }^{133}$ See, "Former Fed Official Says Central Bank Should Act to Thwart Trump's Re-Election", William Dudley says Fed must consider politics, sparking blowback from economists. https://www.wsj.com/articles/former-fedofficial-says-central-bank-should-act-to-thwart-trumps-re-election-11566926950 . These people are very dangerous for our economy and the entire world. See also, https://en.wikipedia.org/wiki/William_C._Dudley . In addition, see more information regarding this liberal-globalist economist,

https://www.bing.com/news/search?q=William+Dudley+Of+The+Fed\&qpvt=William+Dudley+of+the+Fed\&F ORM=EWRE

${ }^{134}$ The U.S. central bank has more than $\$ 7$ trillion of assets on its books - the equivalent of more than a quarter of annual U.S. economic output before the crisis. Its stockpile of assets will grow much larger under the litany of programs it has launched, although some will be held in what are known as special-purpose vehicles, or SPVs, rather than directly by the central bank. Fed's assets from $\$ 4.242$ trillion on March 4, 2020, jumped to $\$ 7.082$ trillion on June 24,2020 and on 12/2/2020 reached \$7.223 trillion. See, https://fred.stlouisfed. org/series/WALCL

${ }^{135}$ See, Kallianiotis and Petsas (2020) and Kallianiotis (2018). Europe, on December 21, 2020, remains the epicenter of the coronavirus pandemic - where the outbreak, uncontrolled, morphed into catastrophe. There were 480,572 dead and 21,446,672 infected. And the devastation is far from over and Euro-zone membernations are going back to their previous debt crisis memoranda and austerities. This is the cost for the European citizens of this artificial inhumane union. See, https://www.politico.eu/article/coronavirus-europe-failed-the-test/ . In the U.S. for the same period, there were 16,256,754 infected and 299,177 dead, according to the "scientists". See also,
}

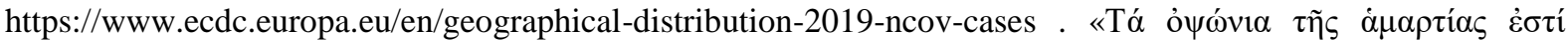
$\theta$ ávatoc.»

${ }^{136}$ See, Key ECB interest rates.

https://www.ecb.europa.eu/stats/policy_and_exchange_rates/key_ecb_interest_rates/html/index.en.html ${ }^{137}$ See, David Daleiden, I was punished for exposing the truth. (12/3/2020).

${ }^{138}$ A half-century ago, "progressives" used to push limitless free expression, blasting conservatives for their allegedly blinkered traditionalism. They boasted of obliterating once-normal boundaries in art, music, and literature to allow nudity, profanity, sexuality, and anti-American boilerplate. Now? The left is Victorianincreasingly puritanical, regressive, and hypersensitive. Even totalitarian censorship and book-burning have weirdly become part of their by-any-means-necessary methods. See, https://www.theconservativedi spatch.com/2020/12/03/why-do-progressives-no-longer-defend-free-expression/

139 Amazon, Facebook, Google, Microsoft, and Twitter are more refined in suppressing books, films, communications, and ideas they don't like — and don't want others to like either. See also, https://www.thele gacyreport.com/big-tech-love-affair-rm/?eid=MKT503096\&src=Powerinbox

${ }_{140}$ President Trump said in his campaign rally in Tulsa, Oklahoma on June 20, 2020 that "I tried to clean the country from the Washington swamp, but I did not know that it was so deep". (Fox News, 6/ 20/2020). Bpopró

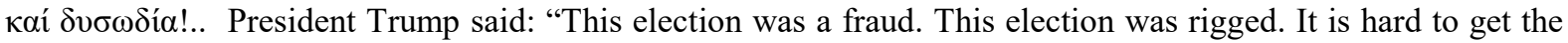
case to the Supreme Court. Mail-in ballots are a disaster." (Fox News, 11/29/2020). "As president, I have no higher duty than to defend the laws and the Constitution of the United States," which - along with the election system - is under "coordinated assault and siege," See, Watch President's Trump "Most Important Speech Ever". https://rawconservativeopinions.com/2020/12/03/watch-president-s-trump-most-important-speech-ever/ 
This new unexpected healthcare, financial, economic, and suspicious social crisis, which was caused by China and the WHO was unique in human history. ${ }^{141}$ The government gave a $\$ 2.2$ trillion stimulus to Americans with the objective to help the destroyed economy. ${ }^{142}$ They destroyed small businesses with this financial crisis and with the lockdown during the coronavirus pandemic; we have abandoned the anti-trust laws and we have created only oligopolies and very soon, there will be only monopolies that were and are open and working during the close down of the other businesses. And in November of 2020, it appeared a "second wave" of the coronavirus (increases in hospitalization and deaths). These unethical practices have destroyed family business and have created enormous unemployment. Also, the streets in the cities were empty with abandoned stores and many businesses still boarded up out of fear of riots. A month ago, no one was walking there, except riots, looters, arsonists, and statues desecrators. And then, it came the election of November 3, 2020 that the Democrats were preparing for four years with only one objective, to win with all the means the presidency and they were "successful", but they lost the legitimacy forever. It is obvious that our democracy does not work ${ }^{143}$ without ethics and morality. China had destroyed countries economically with its unfair competition and now; it has devastated their health, economy, and society. It has to pay reparation to all nations for these destructions. ${ }^{144}$ Consequently, globalization raises many ethical issues and makes the unethical behavior and culture of some nations' global problems.

\section{CONCLuSion}

Ethical behavior is necessary for a business, the market, a society, an individual, a nation, its President, ${ }^{145}$ and the world to survive. You cannot build on lies, corruption, exploitation, lawlessness, anarchy, immorality, perversion, fraud, and deception your existence. People must act with wisdom, courage, integrity, personality, dependability, restraint, respect and self-respect, ${ }^{146}$ and realism. ${ }^{147}$ Markets and businesses must behave with effectiveness, efficiency, consistency, responsibility, and co-operation. ${ }^{148}$ The public policies (monetary, fiscal, trade, etc.) have to be ethical and supportive for all citizens. Nations owe to obey to international laws and fair international agreements and trade. The number one objective of a policy is the welfare of the countries' citizens and not the profitability of its institutions and the wellbeing of the "allies". Regulations and fair laws, equal opportunities and justice, freedom and individual liberties, ethical behavior, respect of human life, democracy, election integrity, and moderation for everything in a society are important for its future.

Philosophy and science ("scientists") cannot offer many things to our society anymore because they have been controlled by the latest political movements. They became immoral and unethical,

\footnotetext{
${ }^{141}$ The objective is one, the reduction of population (the perpetuation of the Malthusian theory). See, https://en.wikipedia.org/wiki/Malthusianism ..

${ }_{142}$ More than one million dead Americans were sent stimulus checks, costing the federal government near $\$ 1.4$ billion in April 2020, a government watchdog reported on June 24, 2020.The size of our government (the establishment) is inefficient. See, https://dailycaller.com/2020/06/25/one-million-dead-americans-stimuluschecks-report-coronavirus/

${ }^{143}$ These corruptions, dishonesty in media and big Tech, fraud, and irregularities cannot be found in any third world country. These are the innovations of the "elites" to demote the traditional American Christian civilization ("the cancel culture movement of the 2020").

${ }^{144}$ The world's deaths were 483,217 and in U.S. they were 121,979 with June 25, 2020. (Fox News). On December 21, 2020, there were: world's deaths 1.7 million and U.S.'s deaths 318 thousands. See, https://www.google.com/search?q=world+deaths+from+COVID-19\&sourceid=ie7\&rls=com.microsoft:enUS:IE-Address\&ie $=\& o e=\& g w s \_r d=s s l \# s p f=1608567760932$. The monetary and economic cost is in thousands of trillions of dollars.

${ }^{145}$ President Trump tries to change this forty years old corrupted (unethical) trend, but he was facing enormous opposition from the liberals (globalists) by using all their "innovated" means and experience since the French Revolution (1789); like Russia $=>$ Ukraine $\Rightarrow$ impeachment $\Rightarrow$ coronavirus $\Rightarrow>$ lockdown insanity $=>$ economic crisis $=>$ civil unrest $=>$ "autonomous zones" $=>$ destruction of monuments $\Rightarrow>$ defund the policy $=>$ cultural revolution $=>$ distortion of history $=>$ keep schools closed $=>$ mail-in voting $=>$ voter fraud. etc. (Sic).

${ }^{146}$ A basic virtue for humans is "the fear of God" until they reach "the love for God".

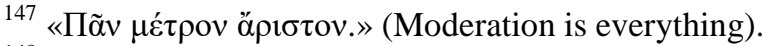

${ }^{148}$ Of course, the first priority must be the citizens and the country and not the "allies", as a U.S. President said to some representatives from the shoe industry, when they visit him in 1980s and asked to do something with the unfair trade and imports of shoes from developing countries. His response was, "the allies first". These liberals are in power for half a century and the country has reached the point that it is today, "dead end".
} 
politicized, followers of their financiers (grants offerors), and end up ignorant. This is a very big crisis of our world, today. People have no objective instructors, guiders, and advisers; they have become pseudo-scientists. Then, what is the remedy? Back to our traditional values (to moral philosophers and revelation) that led humanity for three thousands years. With wrong decisions ( $\left.\dot{\alpha} \mu \alpha \tau_{i} \alpha \varsigma\right)$ an individual will destroy himself, his family, and his inheritance. Then, with wrong public policies, they destroy the lives of millions of people, the entire country, and even the lives of the future generations. Thus, the policy makers, it is absolutely necessary to be ethical, moral, and knowledgeable, with enormous practical experience. Ignorant people cannot do these kinds of jobs; they cannot be decision makers.

The last two crises are very suspicious economic and social ones; but, they show our wrong direction and prove the weakness of our world, today. The deregulation of our markets and institutions, since 1980, has contributed to these crises together with the unethical public policies, unfair trade, outsourcing, globalization, and dependency on foreign economies with different value-system governments. There is no excuse for a local coronavirus mistake in Wuhan to leave it and become a global pandemic with infinite cost in human lives ${ }^{149}$ and global economic destruction. This happened due to completely lack of basic ethical values, self-respect, and responsibility of different governments and nations. We saw not only political mistakes, especially from the opposition parties, ${ }^{150}$ but also other enormous mistakes, "scientific" ignorance by "experts", by the big Tech firms, and "fake" news and propaganda from the controlled subjective media. All these prove that our world is not only unethical, but under breakdown. This current social crisis (riots, lawlessness, anarchy, looting, burnings, "autonomous zones", destruction of monuments, election irregularities, etc.) in the U.S. is similar to what the Jacobins were doing in France in $1789^{151}$ and also what ISIS was doing in Afghanistan, Iraq, and Syria by destroying their monuments and the culture of these nations. ${ }^{152}$ People around the world have to abandon their current mistakes and go back to the traditional and historical values that slowly and methodically have been taken away. Unfortunately, in our contemporary world there is the seed of evil, the passions (like, hatred, greed, immorality, and lack of ethics, etc.) and became the main cause of disruption of our personal, social, economic, financial, and political life. The ethical struggle has to be continued in our societies, the truth to prevail and the human beings to reach perfection. ${ }^{153}$

\section{REFERENCES}

Blommestein, Hans J. (2006), Enron and World Finance, Enron and World Finance, A Case Study in Ethics, https://www.researchgate.net/publication/304722424_How_to_Restore_Trust_in_Financial_Markets

Beitz, Charles (1999), "Review Article: International Liberalism and Distributive Justice: A Survey of Recent Thought," World Politics 51, pp. 269-296.

Bluhm, William T., and Robert A. Heineman (2007), Ethics and Public Policy: Method and Cases, Prentice Hall.

\footnotetext{
${ }^{149}$ See footnote 144 . See also,

https://www.google.com/search?sxsrf=ALeKk020gvqELHupRW42np5iYlRBdXoBFQ\%3A1593101324625\&ei $=\mathrm{DMz} 0 X \mathrm{Xt} 7 \mathrm{gJY}$ 2eytMP4oiLqAU\&q=what+is+the+number+of +deaths+from+coronavirus+in+the+world\&oq $=\mathrm{w}$ hat+is+the+number+of+deaths+from+coronavirus+in+the+world\&gs_lcp=CgZwc3ktYWIQAzoECCMQJzoCC ABQ0agCWNLFAmDOzAJoAHAAeACAAcEBiAHgC5IBAzkuNZgBAKABAaoBB2d3cy13aXo\&sclient=ps

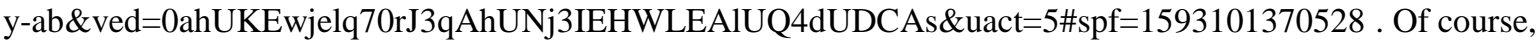
we cannot trust these data because their suppliers have become followers of the big liar. This is our life, today, we renounced the truth and we admit the lie.

${ }^{150}$ In an interview with Dana Perino on Fox News, former Congressman Trey Gowdy expressed his disgust for the lawless environment they fostered in cities across America. https://patriotpulse.net/trey-gowdy-destroyedthe-democrats-with-one-truth-bomb-about-the-riots/

${ }^{151}$ See, https://en.wikipedia.org/wiki/Jacobin_(politics). See also, Victor Davis Hanson, “America's New Jacobins", https://www.hoover.org/research/americas-new-jacobins

152 This orchestrated crisis (revolution, cultural or civil war) in the U.S. is very similar to the French Revolution (1789) and the Bolshevik Revolution in Russia (1917). The objective is exactly the same. See, Kallianiotis (2016 and 2020b).

153 The objective of humans must be:

To Reach Perfection $=\mathrm{f}$ (knowledge of Truth, free will, divine Grace, faith to Christ, personal struggle)

s.t. constraints [external (environment, peers) and internal (war of thoughts) pressure]
} 
Boatright, John (2011), "Ethics in Finance", https://www.researchgate.net/publication/291758092_Ethics_ in_Finance

Deveaux, Monique (2002), "Political Morality and Culture”, Social Theory and Practice. 28 (3), pp. 503-518.

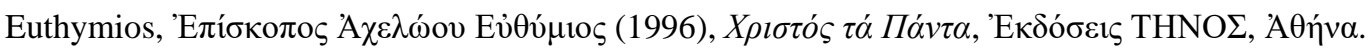

Farla-e-Castro, Miguel (2019), "Can Countercyclical Capital Buffers Help Prevent a Financial Crisis?", ECONOMIC Synopses, pp. 1-2. https://files.stlouisfed.org/files/htdocs/publications/economic-synopses/ 2019/06/21/can-countercyclical-capital-buffers-help-prevent-a-financial-crisis.pdf

Firestone, Simon, Amy Lorenc, and Ben Ranish (2019), “An Empirical Economic Assessment of the Costs and Benefits of Bank Capital in the United States", Federal Reserve Bank of St. Louis, REVIEW, pp. 203230.https://files.stlouisfed.org/files/htdocs/publications/review/2019/07/12/an-empirical-economicassessment-of-the-costs-and-benefits-of-bank-capital-in-the-united-states.pdf

Gutmann, Amy and Dennis Thompson (2006),. Ethics and Politics: Cases and Comments, 4th edition: NelsonHall.

Hampshire, Stuart (1978), Public and Private Morality, Cambridge University Press.

Hans, V. Basil (2020), "Ethics in Financial Services and Financial Markets", https:/www.newskarnataka.com/ opinion/ethics-in-financial-services-and-financial-markets

Hoexter, Michael (2013a), "Via Government’s Fiscal Policy and Regulatory Oversight, Ethical

Values Shape Monetary Value”, New Economic Perspectives, https://neweconomicperspectives.org/ 2013/02/via-governments-fiscal-policy-and-regulatory-oversight-ethical-values-shape-monetaryvalue.html

Hoexter, Michael (2013b), “Austerity: the Political Struggle over Who Controls the Economy's Liquidity”, New Economic Perspectives, https://neweconomicperspectives.org/2013/02/austerity-the-political-struggleover-who-controls-the-economys-liquidity.html

Ihrig, Jane and Scott A. Wolla (2020), "The Fed's New Monetary Policy Tools", PAGE ONE Economics, Federal Reserve Bank of St. Louis, pp. 1-11. https://files.stlouisfed.org/files/htdocs/publications/ page1econ/2020/08/03/the-feds-new-monetary-policy-tools_SE.pdf

Jensen, Michael C. (2002). "Value Maximization, Stakeholder Theory, and the Corporate Objective Function." Business Ethics Quarterly, 12 (2), pp. 235-256. https://www.cambridge.org/core/ journals/business-ethicsquarterly/article/value-maximization-stakeholder-theory-and-the-corporate-objectivefunction/2A9534F1F514F341456BCC39DBFD419A

Kallianiotis, John N. (2020a), "The Two Economic Crises of the 21st Century and the Substitution of Fiscal Policy by Monetary Policy", Chapter 1 in Progress in Economics Research. Volume 45, Albert Tavidze (Editor), pp. 1-91, Hauppauge, N.Y.: Nova Science Publishers, November 2020, ISBN: 978-1-53618-895 (eBook) and ISBN: 1549-1552 https://novapublishers.com/shop/progress-in-economics-research-volume$45 /$

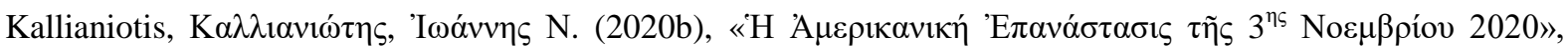

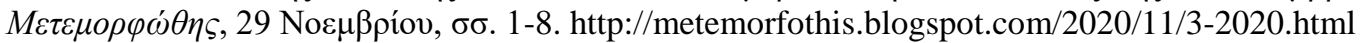

Kallianiotis, I.N. (2020c), “Can Monetary Policy Prevent Financial Crises?”, International Journal of Economics and Financial Research, Volume 6, Number 4, April 2020, pp. 51-75. https://arpgweb.com/ journal/5/archive/04-2020/4/6, https://arpgweb.com/pdf-files/ijefr6(4)51-75.pdf , and https://arpgweb.com/ journal/journal/5

Kallianiotis, J.N. (2019), Foreign Exchange Rates and International Finance, Hauppauge, N.Y.: Nova Science Publishers, October 2019, ISBN: 978-1-53616-550-0. https://novapublishers.com/shop/foreign-exchangerates-and-international-finance/

Kallianiotis, J.N. (2018), The European Union and its Debt Crises: The Deception of the Greeks,

Hauppauge, N.Y.: Nova Science Publishers, August 2018, ISBN: 978-1-53614-067-5. https://novapublishers. com/shop/the-european-union-and-its-debt-crises-the-deception-of-the-greeks/

Kallianiotis, John N. (2017a), "Central Banks, Monetary Policy, and their Efficiency", (Chapter1) in Monetary Policy: Perspectives, Strategies and Challenges, Harriet Ward (editor), New York: Nova Science Publishers.

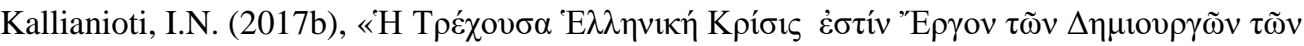

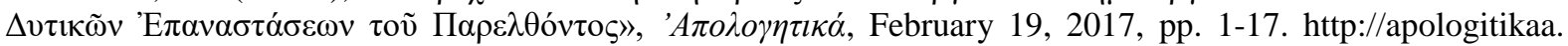
blogspot.com.cy/2017/02/i.html

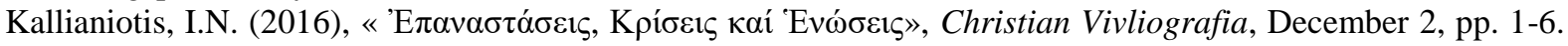
https://christianvivliografia.wordpress.com/2016/12/02/\%e1\%bc $\% 90 \%$ cf\% $80 \%$ ce\%b1\%ce\%bd\%ce\%b1\% cf\% $83 \%$ cf\% $84 \%$ ce $\%$ ac\% $\%$ cf $83 \%$ ce $\%$ b5\%ce\%b9\% $\%$ cf $82-$

$\%$ ce $\%$ ba\%cf\% $81 \%$ ce $\%$ af\%cf\% $83 \%$ ce $\%$ b5\%ce\%b9\%cf\%82-\%ce\%ba\%ce\%b1\%ce\%af-

$\%$ e1\%bc\%91\%ce\%bd\%cf\%8e\%cf\%83\%ce\%b5\%ce\%b9\%cf\%82/ 
Kallianioti, J.N. (2015), “The Latest 'Planned' Financial Crisis, Which Caused the First Depression of the $21^{\text {st }}$ Century, Was a Moral and Political Crisis", in Global Financial Crisis: Causes, Consequences and Impact on Economic Growth, Jeanne Barnett (editor), New York: Nova Publishers, December 2015, Chapter 2, pp. $15-78$.

Kallianiotis, I.N. (2002), "Saving and Investment: The Forecast Function of Interest Rate", American Business Review, Vol. XX, No. 1, January, pp. 50-58.

Kallianiotis, I.N. and J. Petsas (2020), "The Effectiveness of the Single Mandate of the ECB and the Dual of the Fed", Journal of Applied Finance \& Banking, Vol. 10, Issue 4, May 1, pp. 115-169. http://www. scienpress.com/journal_focus.asp?main_id=56\&Sub_id=IV\&volid=442 http://www.scienpress.com/journal_focus.asp?main_id=56\&Sub_id=IV\&Issue=1747583 http://www.scienpress.com/Upload/JAFB/Vol\%2010_4_11.pdf

Komlos, John (2019a), “The Real U.S. Unemployment Rate is Twice the Official Rate, and the Phillips Curve", https://www.dropbox.com/s/tooigw05ojqlxnv/real\%20unemployment\%20new.pdf?dl=0.Also, https://drive.google.com/file/d/1913Um32spONxL1QgFgPz6VQxPtYt7Ieb/view?usp=sharing

Komlos, John (2019b), Foundations of Real-World Economics, Second Edition, New York: Routledge.

Leung, Cheuk-Hang (2016), "Cultivating Political Morality for Deliberative Citizens — Rawls and Callan Revisited", Educational Philosophy and Theory, 48 (14), pp. 1426-1441.

Lin, Tom C.W. (2017), "The New Market Manipulation”, Emory Law Journal, July 6, Vol. 66, p.1253. https://papers.ssrn.com/sol3/papers.cfm?abstract_id=2996896

Mendeluk, Paulina (2018), "Public Sphere and the Political Morality in a Liberal Democracy",Analele Universităţii din Oradea, Seria Geografie. 29 (1).

Segal, Troy (2020), “Monetary Policy vs. Fiscal Policy: What's the Difference?", Investopedia, https://www. investopedia.com/ask/answers/100314/whats-difference-between-monetary-policy-and-fiscal-policy.asp

Stark, Andrew (2003), Conflict of Interest in American Public Life, Harvard University Press.

Thompson, Dennis F. (2012), "Political Ethics." International Encyclopedia of Ethics, ed. Hugh LaFollette, Blackwell Publishing.

Thompson, Dennis F. (2005), "The Problem of Many Hands", Cambridge University Press, pp. 11-32. Restoring Responsibility: Ethics in Government, Business and Healthcare,

Thompson, Dennis F. (1987), Political Ethics and Public Office, Harvard University Press.

Wolff, Jonathan (2011), Ethics and Public Policy: A Philosophical Inquiry, Routledge.

\section{AUTHOR's BIOGRAPHY}

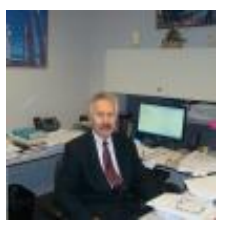

Dr. Ioannis (John) N. Kallianiotis, is a professor of Finance at the Economics/ Finance Department, The Arthur J. Kania School of Management, University of Scranton, Scranton, PA, U.S.A. He has a B.A. in Business from the Aristotelian University of Thessaloniki, Greece (1978), an M.A. in Business Economics from Queens College, CUNY, New York (1982), an M. Phil. in Financial Economics from Graduate Center, CUNY, New York (1984), and a Ph. D. in Finance (International Finance and Monetary Theory \& Financial Institutions) from Graduate Center and Baruch College, CUNY, New York (1986). He has taught to nine different Colleges and Universities for the last thirty-six years and has worked to a few other jobs (as Accountant and Banker) in the private sector for five years. His research interest is on International Finance, Financial Markets, European Union, Public Policy, Political Economy and Economic History, Business and Social Issues in general. His publications are numerous (over 420) in journals, magazines, books, and papers.

E-mail: ioannis.kallianiotis@scranton.edu

Web: http://matrix.scranton.edu/academics/ksom/eco-fin/faculty/John-Kallianiotis.shtml

Citation: Dr. Ioannis N. Kallianiotis "Ethics in Finance, Public Policies, and Institutions: The Latest Financial and Social Crises" International Journal of Managerial Studies and Research (IJMSR), vol 9, no. 1, 2021, pp. 13-41. doi: https://doi.org/10.20431/2349-0349.0901003.

Copyright: () 2021 Authors. This is an open-access article distributed under the terms of the Creative Commons Attribution License, which permits unrestricted use, distribution, and reproduction in any medium, provided the original author and source are credited. 